Florida International University

FIU Digital Commons

5-15-2014

\title{
What Does Board Capital Really Bring to the Table? Exploring the Effect of Directors' Human and Social Capital on Effective Governance During International Expansion
}

Whitney G. Douglas Fernandez

Florida International University, wdoug002@fiu.edu

DOI: $10.25148 /$ etd.FI14071192

Follow this and additional works at: https://digitalcommons.fiu.edu/etd

\section{Recommended Citation}

Douglas Fernandez, Whitney G., "What Does Board Capital Really Bring to the Table? Exploring the Effect of Directors' Human and Social Capital on Effective Governance During International Expansion" (2014). FIU Electronic Theses and Dissertations. 1561.

https://digitalcommons.fiu.edu/etd/1561 


\title{
FLORIDA INTERNATIONAL UNIVERSITY \\ Miami, Florida
}

\section{WHAT DOES BOARD CAPITAL REALLY BRING TO THE TABLE? EXPLORING THE EFFECT OF DIRECTORS' HUMAN AND SOCIAL CAPITAL ON EFFECTIVE GOVERNANCE DURING INTERNATIONAL EXPANSION}

A dissertation submitted in partial fulfillment of

\author{
the requirements for the degree of \\ DOCTOR OF PHILOSOPHY \\ in
}

BUSINESS ADMINSTRATION

by

Whitney G. Douglas Fernandez 
To: Dean David R. Klock

College of Business Administration

This dissertation, written by Whitney G. Douglas Fernandez, and entitled What Does Board Capital Really Bring to the Table? Exploring the Effect of Directors' Human and Social Capital on Effective Governance During International Expansion, having been approved in respect to style and intellectual content, is referred to you for judgment.

We have read this dissertation and recommend that it be approved.

Maria Aysa-Lastra

Carolina Gomez

Ronaldo Parente

Laszlo Tihanyi

Sumit Kundu, Major Professor

Date of Defense: May 15, 2014

The dissertation of Whitney G. Douglas Fernandez is approved.

Dean David R. Klock

College of Business Administration

Dean Lakshmi N. Reddi

University Graduate School

Florida International University, 2014 


\section{DEDICATION}

To my beloved grandparents and my mother, whose sacrifices made all things possible. 


\section{ACKNOWLEDGMENTS}

A well-known Yoruba proverb states, "if we stand tall it is because we stand on the shoulders of many ancestors". I want to take this opportunity to honor and acknowledge my ancestors, upon whose shoulders I stand today. I do not know many of your names nor the languages you spoke. I do not know where you were born or where you died. But I thank you for surviving and enduring the unimaginable. I stand in awe of your strength and your tenacity. I am honored and humbled to carry your blood in my veins. As I celebrate this milestone, I recognize that this achievement is not mine alone. Without you, there is no me. I am you. So I congratulate you, my ancestors, on this tremendous accomplishment. I vow to always remember and give voice to your legacy and sacrifice in all that I do. Thank you.

To my beautiful grandparents, Tom and Edrin: thank you for raising me into the man I am today. Thank you for always believing in me, even when I did not believe in myself. Thank you for working hard and overcoming countless adversities in order to afford your children and grandchildren opportunities you never had. And most of all, thank you for your unconditional love, which has left my heart so full that it is difficult for me to find the words to fully express its sentiments. Though you are no longer here with me physically, I love you always and hope I am making you proud donde quiera que estén. Que descansen eternamente en paz mis abuelitos.

I am blessed to have so many special friends and family members who have enriched my life beyond measure. While I do not have the space to acknowledge each of you individually, please know that every one of you has touched my life in your own unique way. To my mother, who gave me life and embodies the word survivor; to my 
Tias Rita and Lucia, who kept me sane (and well-fed) throughout this doctoral journey: to my primo Laz, who was always there to provide me with a wealth of laughs and encouragement throughout this process; to my sisters and brother, aunts and uncles, and all my family and friends, I thank you for your love, your support, and your lessons over the years. God bless you all.

To the members of my dissertation committee, Drs. Maria Aysa-Lastra, Carolina Gomez, Ronaldo Parente, Laszlo Tihanyi, and my major professor Sumit Kundu, I want to express my sincerest gratitude for your guidance and patience throughout my academic journey. I also thank my other faculty mentors, Drs. Meredith Burnett, Jorge Rivera, and Bill Schneper, who have all played an enormous role in my development over the years. To Jennifer Spencer and all of the faculty and staff at the George Washington University CIBER program, thank you so much for the opportunity to work with you at the Summer Doctoral Institute. It was an incredible learning experience.

To Nelis, Rosa, Liz, Ramón, Jerrik, Cassandra, and all the other staff members of the Department of Management and International Business, thank you for being the most efficient and friendly group of people I have ever met. You all brightened many of my days throughout this journey. I also want to acknowledge Jessica Mari and Cristobal Ruiz, the PhD program coordinators, whose knowledge and professionalism made the administrative part of this process a breeze for me. 


\begin{abstract}
OF THE DISSERTATION
WHAT DOES BOARD CAPITAL REALLY BRING TO THE TABLE? EXPLORING THE EFFECT OF DIRECTORS' HUMAN AND SOCIAL CAPITAL ON EFFECTIVE GOVERNANCE DURING INTERNATIONAL EXPANSION
\end{abstract}

by

Whitney G. Douglas Fernandez

Florida International University, 2014

Miami, Florida

Professor Sumit Kundu, Major Professor

What constitutes effective corporate governance? Which director characteristics render boards effective at positively influencing firm-level performance outcomes? This dissertation examines these questions by taking a multilevel, multidisciplinary approach to corporate governance. I explore the individual-, team-, and firm- level factors that enable directors to serve effectively as strategic resources during international expansion. I argue that directors' international experience improves their ability to serve as effective strategic consultants and resource providers to firms during the complex internationalization process. However, unlike prior research, which tends to assume that directors with the potential to provide important resources uniformly do so, I acknowledge contextual factors (i.e. board cohesiveness, strategic relevance of directors' experience) that affect their propensity to actually influence outcomes. I explore these issues in three essays: one review essay and two empirical essays.

In the first empirical essay, I integrate resource dependence theory with insights from social-psychological research to explore the influence of board capital on firms' 
cross-border M\&A performance. Using a sample of cross-border M\&As completed by S\&P 500 firms from 2004-2009, I find evidence that directors' depth of international experience is associated with superior pre-deal outcomes. This suggests that boards' deep, market-specific knowledge is valuable during the target selection phase. I further find that directors' breadth of international experience is associated with superior postdeal performance, suggesting that these directors' global mindset helps firms in the postM\&A integration phase. I also find that these relationships are positively moderated by board cohesiveness, measured by boards' internal social ties.

In the second empirical essay, I explore the boundary conditions of international board capital by examining how the characteristics of firms' internationalization strategy moderate the relationship between board capital and firm performance. Using a panel of 377 S\&P 500 firms observed from 2004-2011, I find that boards' depth of international experience and social capital are more important during early stages of internationalization, when firms tend to lack market knowledge and legitimacy in the host markets. On the other hand, I find that breadth of international experience has a stronger relationship with performance when firms' have higher scope of internationalization, when information-processing demands are higher. 
TABLE OF CONTENTS

CHAPTER

PAGE

ESSAY 1: WHAT DOES BOARD CAPITAL REALLY BRING TO THE TABLE?

REVIEWING THE RESOURCE PROVISION ROLE OF BOARDS ...........................

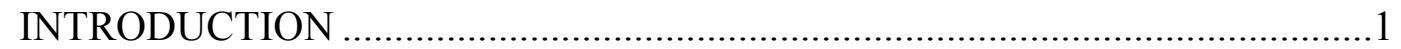

RESOURCE DEPENDENCE THEORY ...........................................................

WHAT WE KNOW: THE RESOURCE PROVISION ROLE OF BOARDS ........5

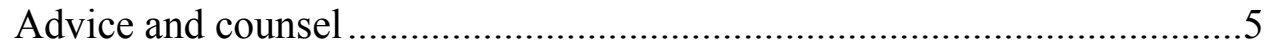

Access to information channels ........................................................... 8

Preferential access to critical resources ................................................ 9

Legitimacy ................................................................................... 10

AN AGENDA FOR FUTURE RESEARCH................................................ 12

ESSAY 2: BOARD CAPITAL AND CROSS-BORDER M\&A PERFORMANCE:

THE MODERATING ROLE OF INTERNAL SOCIAL TIES …..................................15

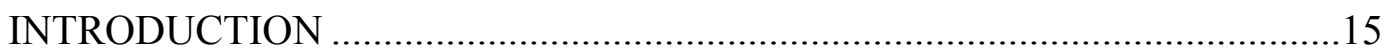

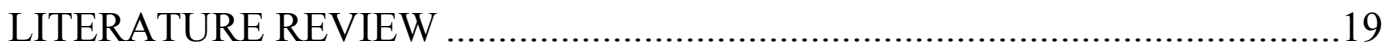

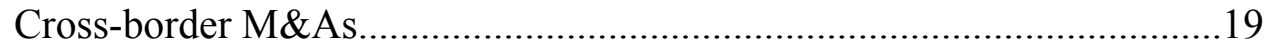

The resource provision role of boards ..................................................22

Social-psychological research on boards .............................................25

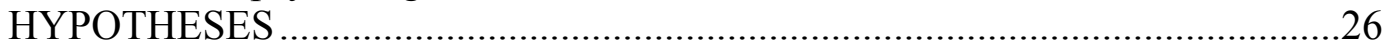

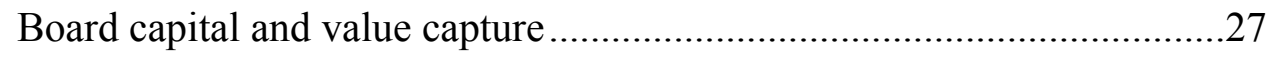

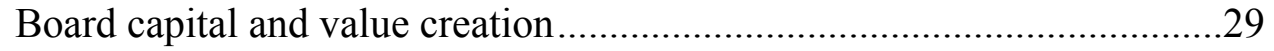

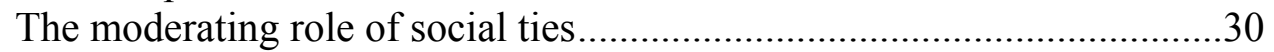

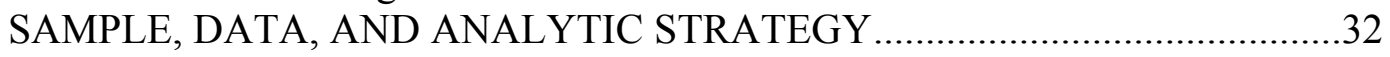

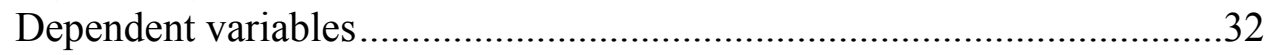

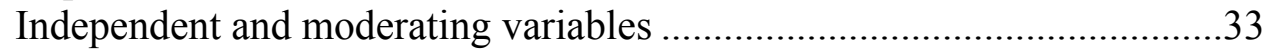

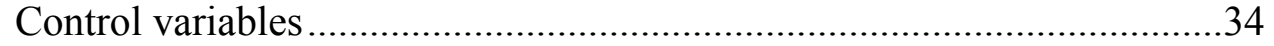

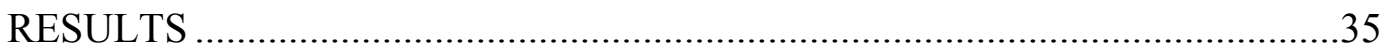

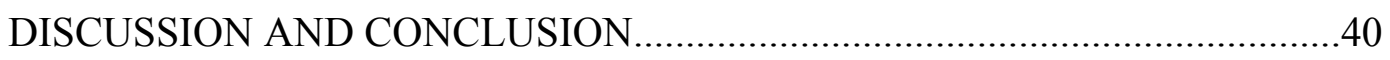

ESSAY 3: INTERNATIONAL BOARD CAPITAL AND MNE PERFORMANCE:

THE MODERATING EFFECTS OF INTERNATIONALIZATION SCALE AND

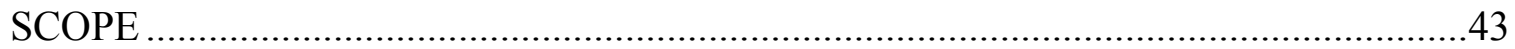

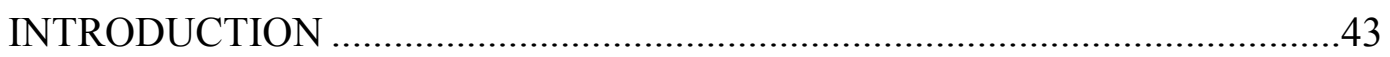

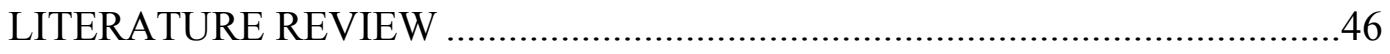

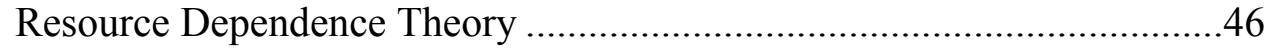

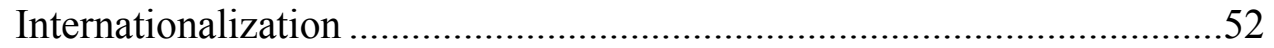

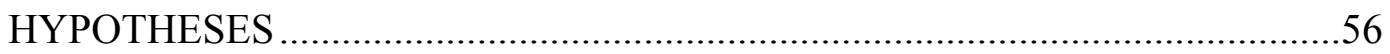

International Board Capital and MNE Performance..............................56

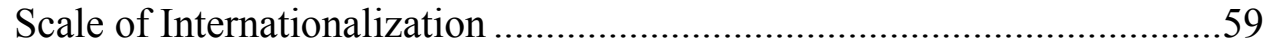

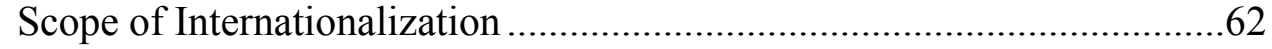




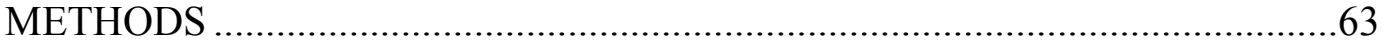

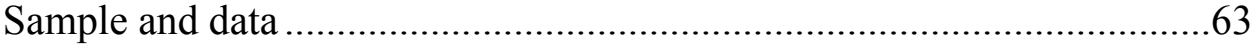

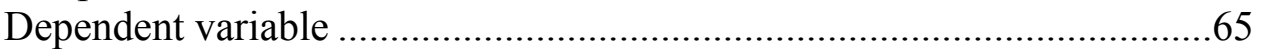

Independent and moderating variables ....................................................66

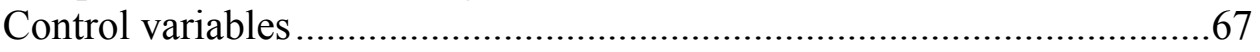

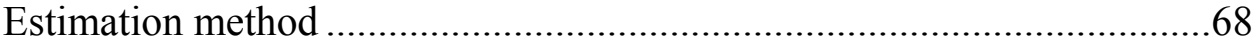

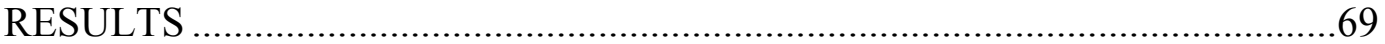

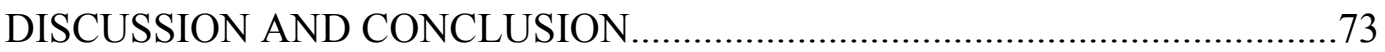

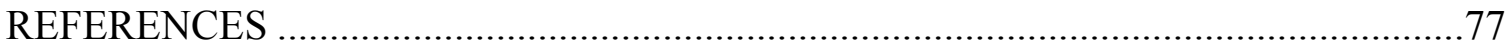

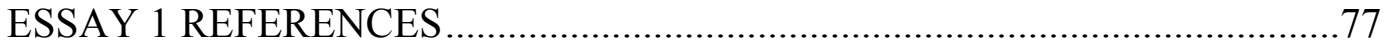

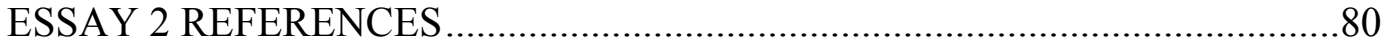

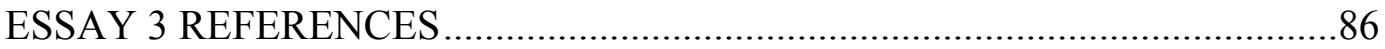

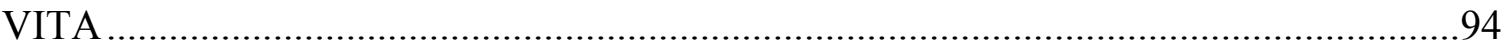




\section{LIST OF TABLES}

TABLE

PAGE

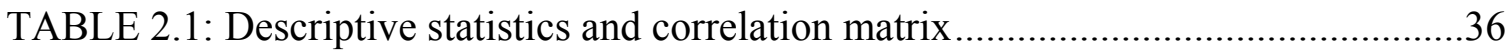

TABLE 2.2: Regression estimates for value capture ...............................................37

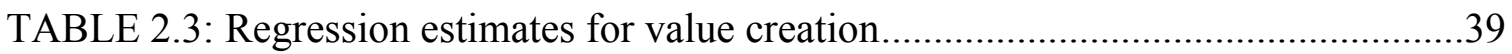

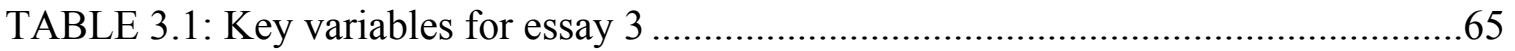

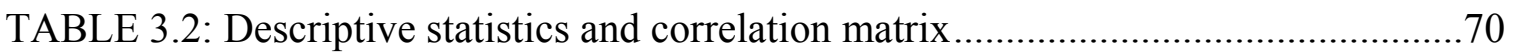

TABLE 3.3: GEE analysis results for the effect of board capital on MNE performance..71 


\section{ESSAY 1: WHAT DOES BOARD CAPITAL REALLY BRING TO THE TABLE? REVIEWING THE RESOURCE PROVISION ROLE OF BOARDS}

\section{INTRODUCTION}

Management and organization scholars have long acknowledged that boards of directors (hereafter referred to as boards) serve an important function in monitoring the actions managers on behalf of shareholders (e.g. Fama, 1980; Jensen \& Meckling, 1976). This research, rooted in agency theory, argues that due to the separation of ownership and control in modern corporations, managers have the opportunity to act in their own selfinterest and to the detriment of shareholders (Berle \& Means, 1932; Lynell, Golden, \& Hillman, 2003). By monitoring the actions of top managers, boards serve as an important mechanism to protect shareholders against this managerial self-interest. A fundamental assumption of board research from this perspective is that boards should be largely, if not exclusively, composed of independent, outside directors (Daily, Dalton, \& Cannella, 2003). This independence from executives enables directors to be objective in their monitoring duties and therefore more effective as a governing body. Although this conventional view certainly informs an important function of boards, it neglects the role of boards in influencing the strategic direction and outcomes of firms. This perspective is also limited in that it does not have many implications for the composition of boards beyond independence. Thus, the agency theory perspective does not provide a full picture of the strategic role of boards within firms.

Resource dependence theory provides a theoretical foundation for another important function of the board: the boards' resource provision role (Daily et al., 2003; 
Pfeffer \& Salancik, 1978). In addition to monitoring executives, boards serve as boundary spanners through which firms access important resources from the external world upon which they depend for survival (e.g. Pfeffer \& Salancik, 1978). Among the most notable resources boards provide are advice and counsel on important strategic issues, access to information channels with external organizations, preferential access to valuable resources through personal connections, and legitimacy with key stakeholders (Pfeffer \& Salancik, 1978). An important implication of resource dependence theory is that each director may bring different linkages and resources to the board (Lynall, Golden, Hillman, 2003) based on their diverse backgrounds and experiences. This proposition from resource dependence theory has inspired a substantial body of research that explores the effect of a broad range of board characteristics in providing essential resources to firms, and ultimately influencing firms' strategic actions and outcomes (Davis \& Cobb, 2010). The construct board capital, a construct that represents the composite of the human and social capital of the board, is intended to capture the ability of the board to provide resources to the firm (Hillman \& Dalziel, 2003).

Despite the growing body of research dedicated to exploring the effect of board capital on the provision of resources to firms, no systematic review of the resource provision role of boards has been published. In order to take stock of the literature on the resource provision role of boards, I reviewed theoretical and empirical studies published in leading management journals from 1978 through 2013. Following previous research (e.g. Johnson, Schnatterly, \& Hill, 2013; Short, 2009), I included all articles from Academy of Management Journal (AMJ), Academy of Management Review (AMR), Administrative Science Quarterly (ASQ), Journal of Management (JOM), Journal of 
Management Studies (JMS), Organization Science (OS), and Strategic Management Journal (SMJ). Additionally, I included articles from two specialty journals: Journal of International Business Studies (JIBS), and Corporate Governance: An International Review (CG). Further, I extended my review by also searching the references of articles returned in my first search to identify additional articles. Following Johnson and colleagues (2013), I removed studies in which the hypotheses or propositions were unrelated to board capital, those that did not address board characteristics other than size and independence, and those that merged the characteristics of the board with non-board member managers, thus confounding the effect of the board capital on the provision of strategic resources.

The remainder of this manuscript proceeds as follows. First, I provide a brief background of resource dependence theory, with a particular focus on the theory's propositions regarding boards' resource provision role. I then turn my attention to taking stock of what we currently know about the role of directors' human and social capital in enabling boards to provide each of the four strategic resources to firms. Finally, I highlight gaps in the literature and suggest promising new avenues of future research on the resource provision role of boards.

\section{RESOURCE DEPENDENCE THEORY}

Resource dependence theory was originally developed as an alternative to the economic theories of mergers and board interlocks that had dominated the literature (Davis \& Cobb, 2010; Pfeffer, 2003). Resource dependence theory takes its conceptual roots in Thompson's (1967) open system view of organizations, in which firms are dependent on external organizations and environmental contingencies for their survival 
(Pfeffer \& Salancik, 1978; Lynall, Golden, \& Hillman, 2003). These dependencies create risk and uncertainty, which in turn affects firms' performance. In other words, a firm's survival and performance depends on its ability to acquire scarce, yet essential resources from the external environment (Pfeffer \& Salancik, 1978; Wernerfelt, 1984). Resource dependence theory suggests that firms can minimize their uncertainty and dependence on exchange partners by engaging in a number of strategic actions that link firms to their external environments. The strategic cooptation of directors with important external linkages is among the most common and effective of these actions.

Boards play a crucial role in helping firms to manage external dependencies and reduce environmental uncertainty by providing critical strategic resources and linkages to audiences that provide or mediate access to these resources (Lynall, Golden, \& Hillman, 2003; Pfeffer, 1972). By having directors who serve to link the organization with its external environment, a board may act to reduce uncertainty and increase performance. A fundamental proposition of resource dependence theory is that the need for environmental linkages is a direct function of the levels and types of dependence facing an organization (Hillman, Cannella, \& Paetzold, 2000; Pfeffer \& Salancik, 1978). Accordingly, the theory predicts a relationship between the degree and nature of firms' dependencies and the composition of the board.

Boards primarily provide firms with four types of resources: advice and counsel on important strategic decisions, channels for communicating information between the firm and external organizations, assistance in obtaining resources or commitments from important constituents outside the firm, and legitimacy. In order to provide firms with these resources, boards leverage their human and social capital (Hillman \& Dalziel, 
2003). Human capital refers to directors' innate and learned abilities gained through education, training, and work experience (Becker, 1975; Sundaramurthy, Pukthuanthong, $\&$ Kor, 2013). Social capital, on the other hand, refers to directors' socially valuable attributes (Johnson, Schnatterly, Bolton, \& Tuggle, 2011) as well as their ability to access information and resources through their social relationships and networks (Kor \& Sundaramurthy, 2009; Nahapiet \& Ghoshal, 1998; Sundaramurthy et al., 2013). Boards with higher levels of certain forms of capital should be able to serve their resource provisional roles more effectively than others with regard to corresponding strategies and subsequent performance (Haynes \& Hillman, 2010).

Resource dependence theory has received more empirical support than any other theoretical lens applied to board research, including agency theory (Davis \& Cobb, 2010; Hillman, Withers, \& Collins, 2009; Johnson, Ellstrand, \& Daily, 1996). Thus, examining how boards use their human and social capital to provide strategic resources to firms has proven a fruitful venue for understanding the function of boards. In the next section, I review the extant literature on boards' resource provision role.

\section{WHAT WE KNOW: THE RESOURCE PROVISION ROLE OF BOARDS}

\section{Advice and counsel}

In recent years, firms have been under considerable pressure from stakeholders to increase boards' role in strategy formulation (Westphal \& Frederickson, 2001). Firms often lack the sufficient knowledge and experience to effectively formulate and implement strategies to compete in today's increasingly competitive and complex business landscape. Boards can serve to advise managers about alternative approaches 
and answer questions about managers' ideas regarding important strategic matters. Advice and counsel from the board can help ensure that diverse perspectives are considered in the decision-making process, faulty or obsolete assumptions are challenged, and an optimal strategic decision is reached (Westphal, 1999).

Directors should be able to serve more effectively as strategic advisors to the extent that they possess the "right" kinds of knowledge and expertise (e.g., Pfeffer \& Salancik, 1978; Carpenter \& Westphal, 2001; Hillman \& Dalziel, 2003). Accordingly, boards' human capital has been linked to the provision of useful advice and counsel to firms. A great deal of extant research has examined the role of boards' human capital in providing the resources proposed by resource dependence theory. With regard to the provision of advice and counsel, boards' human capital, namely educational background, occupation, and work experience, has been consistently linked with firms' strategic behavior. This suggests that directors' knowledge and experiences shape the advice and counsel they provide to firms, which in turn influences firms' strategic actions. Research has found that directors' educational background affects the manner in which they advise and counsel firms. For instance, Dalziel, Gentry, and Bowerman (2011) find that firms invest more in research and development when their boards have higher representation from Ivy League institutions (where the benefits of research are strongly promoted).

While relatively few studies have linked boards' educational background with their provision of advice and counsel, there are far more studies that explore the effect of directors' occupation and work experience on their ability to serve as effective advisors. Some studies look at how the representation of a diverse set of occupational backgrounds 
amongst directors may affect boards' advice and counsel. For example, Golden and Zajac (2001) find that boards with a large degree of occupational heterogeneity are positively associated with strategic change, suggesting that diversity in directors' experiences and expertise give them a broader variety of strategic options with which to advise firms.

In addition to team-level occupational heterogeneity, the representation of certain types of occupations amongst directors has also been linked with the provision of strategic advice and counsel. Hillman, Cannella, and Paetzold (2000) propose a taxonomy of directors based on their occupation. They classify directors into four categories: insiders, business experts (i.e. CEOs and senior executives of large for-profit firms), support specialists (i.e. lawyers, bankers, public relations experts, etc.), and community influentials (i.e. politicians, community organization leaders, university faculty, etc.). Each type of director provides distinct resources to firms, particularly with regard to the provision of advice and counsel. Using this taxonomy, they predict and find support for their hypotheses: under regulation, boards tend to be composed of more insiders and support specialists, while under deregulation boards have more representation from business experts and community influentials. These findings suggest that in the face of major changes in the external environment, firms look to directors with certain expertise for advice on how to deal with this increased uncertainty.

Stearns and Mizruchi (1993) find that the types of financial institutions represented on a board affect the financing the firms obtain, suggesting that directors' occupations frame the strategic advice they provide to firms. Both Hillman (2005) and Lester and colleagues (2008) find that government officials on the board can provide unique advice and counsel regarding the public policy process, which due to its 
complexity is often very expensive or difficult for a firm to obtain. Other studies have found evidence that directors with relevant experience in a particular industry (e.g. Kroll, Walters, \& Wright, 2008) or with a particular strategic behavior such as acquisitions (e.g. McDonald et al., 2008) provide superior advice and counsel, which in turns leads to superior firm performance. Thus, there is a great deal of empirical evidence to support the claim that boards' human capital, particularly relevant occupation and work experience, provides them with the ability to provide firms with advice and counsel on important strategic matters.

\section{Access to information channels}

When firms are considering complex strategic decisions in an uncertain environment, they often look for information from the actions of other firms to serve as a guide (Connelly et al., 2011). Boards can serve as conduits of information between firms and constituents in their external environment. Directors often bring back important information about strategies, practices, and other important matters to firms. These information channels allow firms to observe the actions of other firms and learn from their successes and failures in order to reduce uncertainty about strategic decisions (Haunschild \& Beckman, 1998). This can also broaden the range of strategic options considered by firms, provide fresh perspectives and expertise, and allow firms to managers identify promising strategic opportunities (Carpenter \& Westphal, 2001; Pfeffer \& Salancik, 1978).

Extant research has found that directors' social capital is particularly useful in providing access to information channels. The most commonly studied form of boards' social capital is the interlock, which occurs when a director of one firm's board sits on 
the board of another. The flow of interorganizational knowledge through board interlocks is one of the most powerful means through which firms can obtain useful information about strategies and best practices (Haunschild \& Beckman, 1998). Board interlocks provide a forum for the corporate elites of multiple firms to meet and discuss issues of strategic relevance, giving directors the opportunity to gain insights about novel practices and bring this information back to the focal firm (Mizruchi, Stearns, \& Marquis, 2006). This embeds decision makers and their firms in a network that aids them in identifying and evaluating emerging strategies in the business community (Connelly et al, 2011). Existing research has linked board interlocks with a wide range of firm behaviors, including corporate philanthropy (e.g. Galaskiewicz \& Wasserman, 1989), mergers and acquisitions (e.g. Haunschild, 1993), adoption of takeover defense strategies (e.g. Davis, 1991), adoption of new organizational structures (Palmer et al., 1993), political contributions (e.g. Mizruchi, 1992), private equity deals (Stuart \& Yim, 2010) and the successful expansion into new, emerging markets (Connelly, Johnson, Tihanyi, \& Ellstrand, 2011).

\section{Preferential access to critical resources}

A key tenet of resource dependence theory is that no organization is completely self-sufficient, and thus all firms are dependent upon external resources for their survival (Pfeffer \& Salancik 1978). Boards can serve to provide firms with preferential access to commitments, support, and resources from important elements outside the firm. Directors' relationships with certain external constituencies and stakeholders can enhance communication between the firm and these stakeholders, thereby facilitating the acquisition of critical resources from them (Boeker \& Goodstein 1991; Pfeffer \& 
Salancik, 1978; Zheng, 2013). Most notably, directors can facilitate access to the tangible and intangible resources that make up a firm's operational requirements such as finance, equipment, or talented employees.

Extant research has linked boards' social capital to their ability to provide access to critical strategic resources. For instance, Mizruchi and Stearns (1994) find evidence that directors who work at financial institutions may not only provide advice regarding external financing, but also may serve as an important facilitator of these funds in tight capital markets. Provan, Beyer, and Kruytbosch (1980) find that links with the community, including board influence within the community, is a significant predictor of potential power that firms gain over resource providers. In a related study, Provan (1980) found that board prestige within the community was associated with increased fundraising ability for firms. Another group of studies has explored how having wellknown, powerful directors such as government officials help firms to gain necessary resources from the political environment (e.g. Hillman, 2005; Lester et al., 2008). Thus, empirical evidence suggests that boards with prestigious, powerful directors with high levels of social capital are able to help firms acquire critical resources from the external environment.

\section{Legitimacy}

Through their board capital, directors can also provide credibility and legitimacy to a firm. This legitimacy gives important external stakeholders, such as suppliers and customers, the sense that the firm is important and will conduct its affairs in a responsible manner. Legitimacy is crucial to firms because it connects them with key stakeholders, on whom the firms depend for resources and survival (Arthaud-Day, Certo, Dalton, \& 
Dalton, 2006; Pfeffer \& Salancik, 1978). Stakeholders view firms that embody prevailing social norms and values as legitimate, and this legitimacy leads stakeholders to trust and support these firms more than non-legitimate firms (Suchman, 1995).

Boards' social capital can play an important role in providing firms with legitimacy. Certo (2003), for instance, finds that prestigious boards improve firms' legitimacy and subsequent IPO performance. Kassinis \& Vafeas (2002) find that the likelihood of a lawsuit decreases with the number of directorships held by outside directors, suggesting that reputable directors act to prevent environmental litigation. Directors can also negatively affect firms' legitimacy when their social capital has been damaged or compromised, leading firms to dismiss the directors in order to defend themselves against legitimacy loss and maintain the support of key stakeholders (Arthaud-Day, Certo, Dalton, \& Dalton, 2006; Cowen \& Marcel, 2011). Thus, there is considerable evidence to suggest that the prestige and social ties of boards can improve the legitimacy of firms, which in turn has an important effect on firm performance.

Certain demographic characteristics of directors have also been linked to boards' ability to bring legitimacy to firms. As public sentiment has increasingly called for organizations to better reflect the populations they serve, this has put pressure on firms to add women and racial minorities to their boards in order to gain and sustain legitimacy with key stakeholders (Hillman, Cannella, \& Harris, 2002). Firms with certain characteristics may be more susceptible to these legitimacy pressures than others. Hillman, Shropshire, and Cannella (2007), for instance, find that firms with specific forms of environmental dependencies are more likely to have female directors. More specifically, the authors find that larger firms, which are more visible to the public, and 
firms in industries that are heavily dependent on female employees are more likely to have female representation on their boards.

\section{AN AGENDA FOR FUTURE RESEARCH}

Taking the aforementioned findings together, boards' human capital appears to have an important effect on the provision of advice and counsel, while social capital affects more boards' ability to provide access to information, strategic resources, and legitimacy with key stakeholders. While these studies have yielded a number of important insights, a great deal of work remains before we can fully understand the resource provision role of boards. Over the course of this review, two main themes have emerged as important ways through which researchers can resolve past contradictions and clarify the literature going forward: (1) theoretical/conceptual issues, (2) methodological issues. I explore each of these areas in the following paragraphs.

One key deficiency of the extant literature is the lack of refinement in the consideration of specific director characteristics that allow directors to effectively execute the four resource provision functions. Few empirical studies have attempted to delineate the nature and sources of board capital that might be linked to the relative success of specific firm strategic actions. Thus, insufficient attention has been given to the boundary conditions under which specific forms of board capital might have stronger or weaker effects on performance outcomes (McDonald et al., 2008). Accordingly, there is a great deal of room for clarification and refinement in the literature with regard to understanding how specific forms of board capital can serve to fill the voids of firms lacking the resources needed to successfully execute a particular strategy. 
Future research should focus on facilitating a better understanding of the bundle of resources, skills, and ties the board can put into use for the firm and providing further insight into how these dimensions shape boards' functions and effectiveness. In addition to refining board capital measures and providing tighter theoretical arguments for the effect of specific forms of capital on the success of corresponding strategies, another opportunity is integrate complementary theories with resource dependence theory to examine boards. Corporate governance is inherently interdisciplinary in nature, so it seems logical that integrating insights from other theories such as agency theory, socialpsychological research, or signaling theory would yield impactful and novel insights into the functioning of boards.

Another avenue for future research is to apply the resource dependence perspective of boards to new contexts and relatively understudied phenomena. One particularly ripe opportunity for future research is the application of resource dependence theory to firms' international strategies. Surprisingly few studies focus on exploring how board capital affects firms' international operations. This is particularly surprising given that boards tend to be most involved role in firms' strategic processes when complex, resource-intensive strategic decisions are being made (e.g. Westphal \& Fredrickson, 2001). Given the risks, uncertainty, and challenges associated with doing business across borders, the resource provision role of boards may be particularly important for firms as they formulate and implement international strategies. Future research should therefore consider how boards serve to link firms to their international environments and accordingly affect their success in these markets. 
Finally, another opportunity for researchers to contribute to our understanding of boards' provision of resources to firms is the collection and analysis of primary data. This limitation is shared by most empirical research on boards, as primary data on boards are notoriously difficult to access (Johnson et al., 2013). However, to the extent that researchers can access primary data through interviews, surveys, or board meeting transcripts, we can shed further insight into the mechanisms through which boards provide strategic resources to firms and how these mechanisms work. These types of new insights could certainly push the board research agenda forward. 
ESSAY 2: BOARD CAPITAL AND CROSS-BORDER M\&A

PERFORMANCE: THE MODERATING ROLE OF INTERNAL SOCIAL TIES

\section{INTRODUCTION}

Cross border mergers and acquisitions (M\&As) continue to be an important strategy for growth in today's fiercely competitive global markets. Cross-border M\&A deals totaled $\$ 944$ billion in 2012, accounting for 36\% of total M\&A activity and up 6\% compared to 2011 cross-border activity (Thomson Reuters, 2012). The popularity of cross-border M\&As is unsurprising, given that they provide acquiring firms with potential gains in the form of access to new markets, increased market power, and the acquisition of important strategic resources and capabilities. Despite their enduring popularity, however, empirical support for the effectiveness of cross-border M\&As as a value-creating strategy for acquiring firms continues to be limited (e.g. Hitt, Harrison, \& Ireland, 2001). While academics have committed a substantial amount of research to the effects of cross-border M\&As on various firm outcomes, no consensus has emerged regarding the antecedents to successful cross-border M\&As (Shimizu, Hitt, Vaidyanath \& Pisano, 2004). This highlights an important question that remains unanswered: how and when do acquiring firms obtain value from cross-border M\&As?

One important factor that has been relatively understudied in this body of literature has been the role of governance mechanisms, namely the board of directors (hereafter boards), in facilitating cross-border M\&A performance. Boards are at the apex of the decision-making process in public corporations (Kassinis \& Vafeas, 2002), and research has suggested that boards play a particularly important role in firms' strategic 
processes when complex, resource-intensive strategic decisions are being made (e.g. Westphal \& Fredrickson, 2001). Resource dependence scholars argue that in addition to their well-established role as monitors, boards serve to advise and counsel managers on strategic decisions and link firms to important external resources necessary to execute their strategies. Thus, the ability of boards to serve effectively as "strategic consultants" for firms during the complex cross-border M\&A process of acquiring across borders is likely an important factor in their ultimate success or failure.

Taking a multitheoretical view of boards, I argue in this paper that "international" board capital affects firms' cross-border M\&A performance. Integrating resource dependence theory with insights from cross-cultural management literature, I argue that firms leverage international board capital in the acquisition process in a way that affects their ability to capture and create value. I argue that international board capital depth (specific, deep experience with the focal market) is an important resource in the preacquisition "due diligence" phase, and thus contributes greatly to value capture (i.e. short-term cumulative abnormal returns from the stock market). On the other hand, international board capital breadth (broad experiences across many countries) will serve as a more important resource during the post-acquisition integration phase, and will therefore contribute to value creation (i.e. long-term accounting performance).

Further, taking a social-psychological view of boards, I introduce a moderator to the aforementioned relationships: internal social ties within the board. Socialpsychological researchers view boards as special cases of workgroups or "supra top management teams", and accordingly explore how team characteristics and dynamics affect board processes, and ultimately their performance (e.g. Forbes \& Milliken, 1999). 
While directors with diverse perspectives, experience, and knowledge have the potential to make positive contributions to firms, the structure and nature of boards can often make it difficult for directors to actually make these contributions. Board cohesiveness, or the degree to which directors are attracted to each other and are motivated to continue serving on the board, can provide directors with international experience the motivation and opportunity to leverage their experience and knowledge to benefit the firm. Thus, I argue that boards with a large degree of internal social ties should be more cohesive, and this allows boards to better leverage the benefits associated with having relevant forms of human and social capital. In other words, board cohesiveness, achieved via internal social ties, contributes to board effectiveness, and thus moderates the relationship between international board capital and cross-border M\&A performance.

This study provides a number of important theoretical and practical contributions. Recent reviews have suggested that research on cross-border M\&As has not kept pace with their surging popularity and strategic importance (e.g. Shimizu et al., 2004). I contribute to research on cross-border M\&As by considering how acquiring firms can use board capital to overcome issues unique to cross-border transactions. Also, whereas most prior research has focused on either pre-deal or post-deal factors, this study examines both pre-deal and post-deal phases to explain cross-border M\&A performance. As predeal and post-deal processes are interrelated yet distinct, we should expect that the role of the board at each phase is also distinct. Therefore, this study provides a more complete picture of governance-related factors that drive success in cross-border M\&As.

Additionally, I extend resource dependence theory by answering the recent call from scholars to further refine the theory by disentangling the types of human/social 
capital needed on the board to provide its proposed benefits (Hillman, Withers, \& Collins, 2009). With the exception of a few notable studies (e.g. Oxelheim \& Randoy, 2003; Staples, 2008), little research has focused on the national/multinational composition of multinationals' boards. Thus, whereas extant literature has focused largely on the "who", "what", and "how" of boards, this study adds the "where" to board capital research by considering the location of directors' work experience in providing them with relevant knowledge to advise firms effectively in the context of international strategy. Also, by deconstructing board capital into breadth and depth components, and exploring the effect of these specific forms of board capital at various phases of the crossborder M\&A process, I elucidate the boundary conditions under which certain forms of board capital has stronger or weaker effects on performance outcomes.

Further, by integrating insights from the social-psychological literature on boards, I provide a fresh perspective on the mechanisms that underlie directors' ability and propensity to influence firm strategies and outcomes. As Johnson and colleagues (2013) point out in their review on board capital and demographics, there is no category of capital that has unequivocal benefits and even diversity of experiences has mixed effects. Thus, I propose that considering social-psychological processes (i.e. team dynamics) within boards is important in helping us to understand mechanisms that affect the degree to which characteristics associated with "potential" to influence outcomes result in the "actual" influence being realized. Finally, the findings clarify for firms the performance implications of having such human capital in their boards, thus providing practical implications for board structure and composition. 
The remainder of this manuscript proceeds as follows. First, I review the relevant literature on cross-border M\&As, resource dependence theory, and social-psychological research on boards. I then turn my attention to developing theoretically driven hypotheses regarding the role of board capital and social ties in facilitating value capture and creation in the cross-border M\&A process. Next, I describe the sample construction and research methodology. Subsequently, I report the results of the study. Finally, I conclude by discussing the findings and providing guidance for future research.

\section{LITERATURE REVIEW}

\section{Cross-border M\&As}

Cross-border M\&As constitute a higher-equity strategy of internationalization and mode of foreign entry (Chakrabarti, Gupta-Mukherjee, \& Jayaraman, 2009). Their potential advantages have been well documented in the international business literature. Cross-border M\&As can provide acquiring firms with economies of scale, access to strategic resources, and new knowledge and capabilities. They also enable acquirers to access foreign markets more quickly than in other modes of entry, and can be less risky than greenfield investments (Stahl \& Voigt, 2008). In today's fiercely competitive global markets, cross-border M\&As offer a seemingly desirable vehicle for much needed growth. It is therefore unsurprising, perhaps, that global cross-border M\&A activity has

continued to rise year after year. While cross-border M\&As present many value-creating opportunities to acquiring firms, they also present a number of challenges that many firms find difficult to surmount in realizing any gains. Uncertainty and information asymmetry in foreign markets make it difficult for firms to adjust and learn from both the local market and target firm (Kogut and Singh, 1988; Zaheer, 1995). 
The continued popularity of cross-border M\&As has spurred considerable research interest among management, international business, and finance scholars. Some of this research has focused on establishing whether cross-border M\&As on average create or destroy value for acquiring firms. However, empirical findings of these studies have been mixed. While some studies find evidence that cross-border M\&As on average provide positive returns for acquirers (e.g., Markides \& Ittner, 1994), others studies find that they destroy value (e.g. Datta \& Puia, 1995; Moeller \& Schlingemann, 2005). These mixed findings highlight the need for research to examine contingencies and processes that may help or impede acquiring firms' ability to extract value from cross-border M\&As.

Accordingly, scholars have attempted to isolate the factors that affect the success of cross-border M\&As. Firms that engage in cross-border M\&As face substantial challenges both pre-acquistion (i.e. target selection) and post-acquisition (i.e. integration), all of which hamper their ability to capture and create value (Hitt et al., 2009). Crossborder M\&A performance is at least partially determined before the deal is ever completed. A host of contextual and process factors determine realizable synergies, and set the stage for the ultimate success or failure of the cross-border M\&A. Some of these factors examined include the type of acquisition (e.g., Datta \& Puia, 1995; Francis, Hasan, \& Sun, 2008), the characteristics of the host country (e.g., Doukas \& Travlos, 1988; Gleason, Mathur, \& Wiggins, 2006), cultural differences (e.g., Chakrabarti, GuptaMukherjee, \& Jayaraman, 2009; Datta \& Puia, 1995) and the nature of acquiring firms' intangible assets (e.g., Markides \& Oyon, 1998; Morck \& Yeung, 1992). 
While pre-acquisition factors are an important consideration, much of the value in cross-border M\&As is lost during the post-acquisition phase. Whereas the pre-acquisition phase is all about identifying potential synergies, the post-acquisition phase is all about reorganizing and integrating in order to realize those synergies. Accordingly, other research has examined the resources and processes that allow for more effective integration, which helps to create and preserve value. The post-acquisition process revolves around reorganization, and this process is complex and demanding on acquiring firms' resources and capabilities. This is because not only must the firm figure out how to reorganize and integrate a new bundle of assets with existing ones, but it must also manage differences in organizational and national culture while also managing important relationships with key stakeholders such as shareholders and employees (Capron \& Guillen, 2009; Haveman and Cohen, 1994; Larsson and Finkelstein, 1999). Managing such relationships may be further complicated by the unfamiliar institutional environment in which the target firm is embedded (Capron \& Guillen, 2009). Active management of organizational cultural integration during all stages of an acquisition becomes necessary to successfully integrate the two firms (Applebaum \& Gandell, 2003). This allows acquiring firms to successfully take the best of both cultures, and effectively recombine them into a new, improved third culture (Hitt et al., 2001).

Viewing these two perspectives as a whole, it is evident that cross-border M\&As have the potential to generate value for acquiring firms under the right conditions. Yet, there is much research left to be done in order to fully understand which conditions constitute the "recipe" for cross-border M\&A success. Additionally, while there is considerable evidence that both pre-deal and post-deal factors are important for the 
ultimate success of cross-border M\&As, few studies examine these factors simultaneously. Also, surprisingly few studies have examined the role of the board in M\&A performance, despite evidence that the board is heavily involved in this process.

As boards have most often been considered from an agency perspective, many studies that examine boards' role in the M\&A process tend to focus on how boards affect firms' choice of M\&A over other modes of foreign entry. For instance, Datta and colleagues (2009) find that firms with boards characterized by a higher proportion of outside directors and independent leadership structures favor M\&As over joint ventures in foreign market entry. While these studies have provided some important insights into how board characteristics may shape cross-border M\&A activity, the agency view faces severe limitations in explaining boards' roles as resource providers and strategic consultants (e.g. Daily et al., 2003). Consequently, with the exception of a few noteworthy empirical studies that evaluate how board experience affects M\&A performance in domestic contexts (e.g. Kroll, Walters, \& Wright, 2008; McDonald, Westphal, \& Graebner, 2008), we currently have a limited understanding of how boards contribute to M\&A performance in general and virtually no evidence of how they contribute to cross-border M\&As.

\section{The resource provision role of boards}

While the monitoring role of boards has traditionally dominated the literature on boards (e.g. Fama \& Jensen, 1983; Jensen \& Meckling, 1976), resource dependence theory provides an alternative view of boards as mechanisms through which firms access important resources from the external world (e.g. Pfeffer \& Salancik, 1978). Resource dependence theory views firms as open systems, dependent on external organizations and 
environmental contingencies (Pfeffer \& Salancik, 1978; Lynall, Golden, \& Hillman, 2003). Accordingly, a firm's survival depends on its ability to acquire needed resources from the external environment (Pfeffer \& Salancik, 1978; Wernerfelt, 1984). Boards play a crucial role in helping firms to manage this external dependence by providing critical strategic resources as well as linkages to audiences that provide or mediate access to resources (Lynall, Golden, \& Hillman, 2003).

Among the critical resources provided by boards are: advice and counsel to the firm on substantial matters such as strategy formulation, access to information outside the firm, preferential access to valuable resources through personal connections, skills and expertise, and legitimacy (Pfeffer \& Salancik, 1978). Boards use their social and human capital to help them provide these resources. Board capital, a construct that represents the composite of the human and social capital of the board, is intended to capture the ability of the board to provide resources to the firm (Hillman \& Dalziel, 2003). Boards with higher levels of certain forms of capital may be able to serve their resource provisional roles more effectively than others with regard to corresponding strategies and subsequent performance.

Indeed, extant research has linked the presence of board capital to a number of firm outcomes, including firm performance (e.g. Hillman, 2005), strategic change (e.g. Haynes \& Hillman, 2010), post-IPO performance (Kroll, Walters, \& Le, 2007), and environmental performance (de Villiers, Naiker, \& van Staden, 2011; Kassinis \& Vafeas, 2002). There is even some evidence in the literature that board capital can affect firms' M\&A performance. For instance, McDonald, Westphal, and Graebner (2008) find that the amount of prior acquisition experience on the board is positively related to post- 
acquisition performance. Similarly, Kroll, Walters, and Wright (2008) found that vigilant boards rich in relevant experience were associated with superior acquisition outcomes. Applied to the context of cross-border M\&As, these findings suggest that boards with certain forms of capital should be able to advise firms effectively throughout both phases of the cross-border M\&A process.

One limitation of extant research is that studies examining director experience most often consider only directors' board experience. However, their primary full-time work experience likely has a more profound effect on shaping their knowledge and skill sets, as well as their cognitive frames and biases. A related limitation is that when studies do consider non-board work experience, there is a tendency to treat all directors from one occupation alike (e.g. Hillman, Cannella, \& Paetzold, 2000). While one's occupation is certainly an important source of expertise, there are other dimensions of directors' work experience that should influence their ability to provide resources for firms (Lester, Hillman, Zardkoohi, \& Cannella, 2008). This study explores the "where" of directors' human capital, by exploring how their international experience can assist directors in providing insight to firms during international expansion activities. Finally, it is also often assumed that director expertise in a particular area will be utilized automatically. However, as boards as composed of "human" experts, there are likely socialpsychological factors at play that ultimately decide if and how directors' expertise are utilized in the decision making process. Thus, this study attempts to address this limitation by considering social-psychological factors within boards that may moderate the relationship between board capital and cross-border M\&A performance. 


\section{Social-psychological research on boards}

Social-psychological research emphasizes the "human" side of corporate governance. Most board research has assumed that where knowledge and skills exist, they will be used (Huse \& Gabrielsson, 2012; Johnson, Schnatterly, \& Hill, 2013). There is a difference between having skills and knowledge and using them (Forbes \& Milliken, 1999). Boards are large, elite, and episodic decision-making groups composed largely of outside, part-time members that face complex tasks pertaining to strategic-issue processing. Owing to the intrinsic characteristics and the nature of their tasks, boards can benefit greatly from the presence of diversity in director attributes. At the same, due to these characteristics, boards are particularly vulnerable to "process losses" (Steiner, 1972) - the interaction difficulties that prevent groups from achieving their full potential. The presence of different viewpoints on less homogeneous boards can cause coordination problems (Forbes \& Milliken, 1999). Furthermore, diversity can corrode group cohesion and lead to a board whose members are less cooperative and experience increased emotional conflict (Lau \& Murnighan, 1998). The effectiveness of boards, therefore, depends heavily on social-psychological processes, particularly those pertaining to group participation and interaction, the exchange of information, and critical discussion (team dynamics and interaction in decision-making).

Process-oriented governance research enables us to "better explain inconsistencies in past research on boards, to disentangle the contributions that multiple theoretical perspectives have to offer in explaining board dynamics, and to clarify the tradeoffs inherent in board design" (Forbes \& Milliken, 1999: 502). According to Forbes and Milliken (1999), there are two criteria of board effectiveness: (1) board task performance, 
defined as the board's ability to perform its control and service tasks effectively, and (2) the board's ability to continue working together, as evidenced by the cohesiveness of the board. Thus, boards' ability to serve firms effectively depends not only on their ability to provide effective advice and monitoring, but also their ability to work together effectively as a team. Board cohesiveness, or the degree to which directors are attracted to each other and are motivated to continue serving on the board, is an important factor in determining how effective boards can utilize their human capital. Cohesiveness affects boards ability to work together effectively. Additionally, directors tend to experience higher levels of satisfaction in cohesive environments than directors in less cohesive environments (Huse \& Gabrielsson, 2012). Directors that are attracted to each other will appreciate coming together for board meetings and give high priority to being part of the board.

Informal relationships, such as those formed through social ties, are a means through which cohesiveness can be achieved, and can create a greater capacity for information sharing and mutual problem solving (Hansen \& Lovas, 2004; Tuggle, Schnattely, \& Johnson, 2010), thus allowing for the positive aspects of diverse capital to be better leveraged. Therefore, in addition to relevant expertise, it is also important to consider the relationships among directors within a board in order to fully understand the ability and propensity of boards to contribute to strategy.

\section{HYPOTHESES}

In the following section, I develop theoretically driven hypotheses relating international board capital to cross-border M\&A performance. My central argument is that boards can provide acquiring firms with important resources that help them overcome the obstacles of cross-border M\&As and achieve superior performance. 
Following Stahl and Voigt (2008), I delineate between value capture and value creation. Value capture refers to the short-term gains resulting from the M\&A transaction itself. In contrast, value creation is a long-term process that requires the realization of operational synergies. I predict that board capital depth is associated with value capture and board capital breadth is associated with value creation. I further predict that these relationships are positively moderated by the presence of internal social ties, which foster board cohesiveness, and in turn affect boards' ability to leverage their relevant capital. An illustration of the hypothesized relationships is presented in Figure 2.1.

Figure 2.1: Conceptual Model

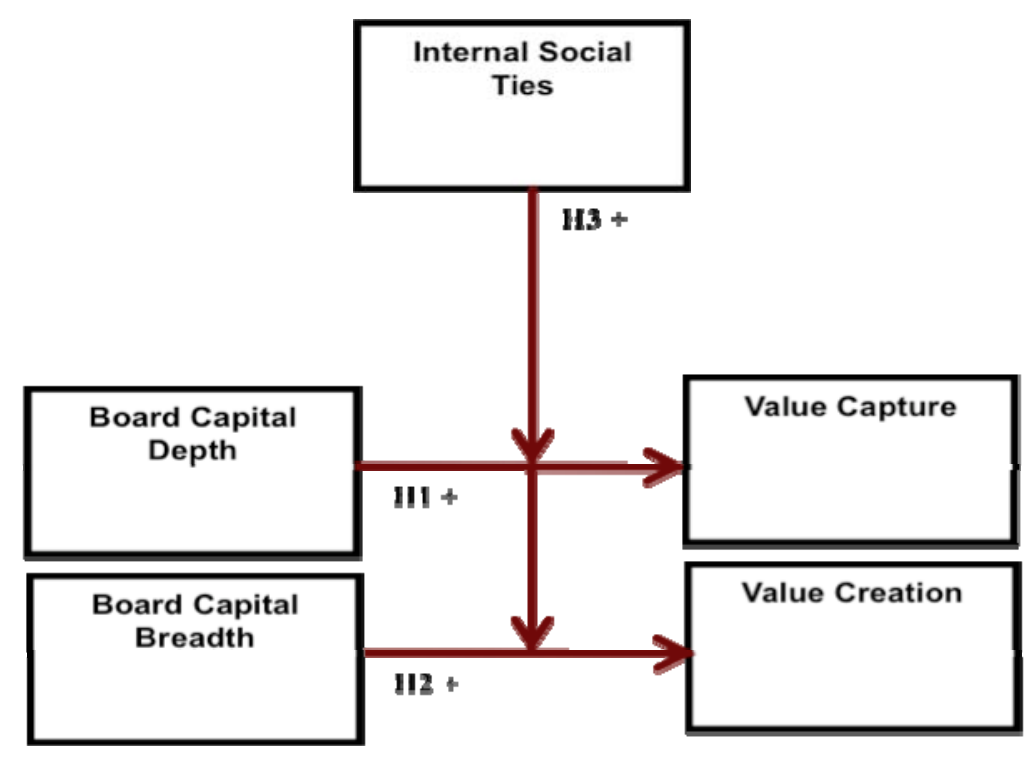

\section{Board capital and value capture}

An essential component of effective target selection is the due diligence process - an objective, independent examination of the acquisition target. During this process, the acquiring firm must learn as much as possible about the target firm, its environment, and any factors that may adversely affect the acquisition's success such as financials, tax matters, asset valuation, operations, the valuation of a business (Shimizu et 
al., 2004). The process is intended to provide the acquirer with adequate information about the value and risks associated with the target firm. Furthermore, the due diligence process should go beyond the mere examination of the financial health of the target firm, providing a thorough analysis of its intangible assets and resources.

Due diligence is a complex process in all M\&As but is even more complicated in cross-border M\&As (Hitt et al., 2001). Cross-border M\&As require special attention to the institutional environment of target firms, including topics such as exchange rates, local taxes, local accounting standards, foreign government potential trade regulations, risk of expropriation, and debt/equity ratios that might be imposed by the foreign government (Kissin \& Herrera, 1990). Further, this process may also require an understanding of the educational system, skills, and capabilities of the work force in the foreign market (Shimizu et al., 2004). Thus, the risk of poor target selection due to insufficient due diligence or lack of relevant expertise is particularly high in cross border M\&As. To ensure value capture, firms need in-depth knowledge of the local culture and institutions in order to select a target with whom potential synergies exist in spite of the inherent risks.

Boards with high levels of international capital can serve as an important resource during this target selection process. Directors who have deep knowledge of the target firm's home country will be able to provide relevant information about the target's local market in the pre-deal decision process. This suggests that these boards are able to effectively advise firms in a manner that will lead to effective due diligence and ultimately better target selection. Thus, to the extent that board members have specific experience with the focal market, they will be able to provide the acquiring firm with a 
wealth of deep market knowledge that will provide for a more accurate assessment of the target firm. In turn, this will allow the firm to capture the value associated with shortterm expectations from the stock market. Thus, I predict:

H1: International board capital depth is positively related to cross-border M\&A value capture.

\section{Board capital and value creation}

In addition to pre-acquisition factors, post-acquisition issues, namely the integration process, can prove overwhelmingly difficult for firms engaging in crossborder M\&As. Whereas due diligence focuses on selecting the right target in order to find potential synergies between the target and acquiring firms, post-acquisition integration is of utmost importance for realizing those potential synergies (Ellis, Reus, \& Lamont, 2009). While effective post-acquisition integration is a major challenge even for domestic M\&As, it is even more difficult to achieve between firms merging across borders (Shimizu et al., 2004). Cultural and institutional disparity between two merging partners is among the usual suspects blamed for ruining cross-border M\&As (Chakrabarti et al., 2009). Acquiring firms face “double-layered acculturation" in cross-border M\&As, which requires them to adapt not only to unfamiliar national cultures and institutions, but also to a new organizational culture (Barkema, Bell, \& Pennings, 1996).

I contend that board capital breadth is a beneficial resource for value creation in cross-border M\&As, as it provides directors with a "global mindset", which is a crucial element in the success of cross-border M\&As (Hitt et al., 2001). Gupta and Govindarajan (2002) define global mindset as a combination of awareness and openness to the diversity of cultures and markets with an inclination and capability to integrate across the diversity. 
Expatriation (i.e. international assignments) enables leaders to gain broader skill sets, cognitive complexity, and extended networks, and is therefore the most powerful strategy to develop globally competent leaders (Gregersen et al., 1998; Lovvorn \& Chen, 2011; Morrison et al., 1999). Directors with a global mindset will have cognitive processes that help them arrive at integrative solutions that balance competing country, business, and functional concerns (e.g. Murtha, Lenway, \& Bagozzi, 1998).

Applied to the post-acquisition integration process, having a global mindset allows acquiring firms to integrate seamlessly with the target into a single new entity, taking the best aspects of both cultures and blending them into a new, improved third culture (Dutton, 1999). These boards will be able to provide advice and counsel for effective post acquisition integration and achieve the elusive synergies that other M\&As try but fail to produce. Thus, board capital breadth should facilitate the development of a global mindset in directors, which in turn allows them to help firms realize synergies through effective post-acquisition integration.

I therefore predict:

H2: International board capital breadth is positively related to cross-border M\&A value creation.

\section{The moderating role of social ties}

An assumption in the boards literature has been that homogenous boards are more effective because they are more cohesive. To the extent that boards are diverse they may lose cohesiveness (Finkelstein et al., 2009). However, a counterargument to this proposition is that to the extent that boards possess different experiences and forms of board capital, they should be able to fulfill their resource provisional roles more 
effectively. The literature on teams suggests that diversity on teams can be a doubleedged sword. On one hand, diversity can allow teams to arrive at more creative, effective solutions since there are a host of diverse perspectives involved in the decision making process. On the other hand, team members tend to share less information with other team members they perceive as dissimilar (Mesner-Mangus \& Dechurch, 2009). I concur that the extent to which boards are able to leverage their board capital effectively does, indeed, depend on their level of cohesion. However, cohesion does not stem from homophily alone. Building on insights from social-psychological research on boards, I propose that social ties among board members also facilitate cohesion, which in turn allows them to realize the gains associated with having diverse forms of board capital and arrive at superior effectiveness with regard to their resource provision roles.

Dense networks facilitate the production of trust and reciprocity (Phelps, 2010) as well as more open communication (Johnson et al., 2012). Additionally, directors who are connected by personal social ties should not only be less reluctant to express their concerns about corporate strategy to each other, but they should also have more frequent opportunities to do so. Therefore, social ties among outside directors should facilitate the voicing of minority opinions and facilitate the discovery of concerns about strategy (Westphal \& Bednar, 2005; Zhu, 2013). In the case of cross-border M\&As, boards that are both rich in relevant international capital boards and cohesive should be able to operate more effectively with regard to providing the necessary resources for superior performance. In the pre-acquisition phase, directors with market-specific knowledge derived from their international experiences will be more motivated to express their viewpoints and will be more likely to have these viewpoints taken sufficiently into 
consideration in target selection. Likewise, in the post-acquisition integration phase, board members' global management capital will be more effectively utilized. Thus, I predict:

H3: The relationship between international board capital and cross-border M\&A performance is positively moderated by internal board ties.

\section{SAMPLE, DATA, AND ANALYTIC STRATEGY}

In order to test these hypotheses, I constructed a sample of cross-border M\&As completed by S\&P 500 firms from 2004-2009. Following prior research, I used the SDC Platinum database to identify deals in excess of US\$100 million in which the acquirers owned 100 percent of their targets after the deals (Ellis, Lamont, Reus, \& Ranft, 2011; Hayward \& Hambrick, 1997). The final sample consisted of 552 transactions completed by 221 firms. Board capital and network data were collected from a variety of sources, including the BoardEx database, the RiskMetrics database, popular press articles, and annual reports. Data on stock returns were obtained from the Center for Research in Securities Pricing $(C R S P)$ database, and data financial and control variables were obtained from Standard \& Poor's COMPUSTAT database.

\section{Dependent variables}

I measured the first dependent variable, value capture, as cumulative abnormal returns (CARs). To calculate CARs, I employed the event study methodology. Following previous studies, I estimated CARs for two event windows: one covering the 3 days prior to, and following the acquisition announcement, and the other covering the 5 days prior to, and following the announcement (e.g. Haleblian \& Finkelstein, 1999; Kroll et al., 
2008). I used the EVENTUS software package, which acquires stock market data directly from the Center for Research in Securities Pricing (CRSP) US stock databases, to calculate CARs for each event.

The second dependent variable, value creation, is measured as the difference in the acquiring firm's return on assets (ROA) three years after the acquisition in relation to one year prior to the acquisition. I chose to use change in ROA as the measure of longterm value creation for several reasons. First, ROA is among the most commonly used measures of accounting performance in management research and is consistent with most M\&A research on long-term M\&A performance (e.g. Ellis et al., 2011; Zollo \& Singh, 2004). Additionally, ROA is an appropriate performance measure due to the relative inability of firm management to manipulate this measure, and that it is less sensitive to estimation bias due to changes in leverage or bargaining power following M\&As (Ellis et al., 2011; Gomez-Mejia \& Palich, 1997). Change in ROA was calculated using data collected from Standard \& Poor's COMPUSTAT database.

\section{Independent and moderating variables}

Board capital depth was measured as the total number of years directors worked in the target's home country. Board capital breadth was measured as the average number of countries in board members had worked. Following prior research (e.g. Adams \& Ferreira, 2009; Scott, 1991), I measured board internal social ties as the percentage of all possible ties among board directors that had been formed. An internal tie can be formed either through mutual affiliation with various "nonbusiness" organizations (i.e. clubs or fraternities, Not-For-Profit organizations (NFP), university boards of trustees, and network clubs), or if two directors earned MBAs from the same school (e.g. Schmidt, 
2008). Board capital data were collected from a variety of sources, including BoardEx, proxy statements, popular press articles and annual reports.

\section{Control Variables}

In order to increase the likelihood of achieving valid results, I controlled the effects of several theoretically relevant variables that might potentially affect the relationships investigated in this study. For instance, larger acquirers possess more assets and resources that may facilitate integration with target firms and increase post-M\&A asset productivity (Healy, Palepu \& Ruback, 1992; Haleblian et al., 2009) Thus, I controlled for acquirer size, measured as the natural logarithm of firm sales. Another factor that may affect the success of an acquisition is the relative size of the acquirer and the target. Thus, I controled for relative size, measured as the ratio of a target firm's total assets one year prior to acquisition to the total assets of the acquiring firm for the same time frame (e.g. Ellis et al., 2011). Acquirer industry can also influence the success of M\&As. To control for any industry effects, I included dummy variables in the model based on firms' 2-digit SIC code.

International acquisition experience may also influence the performance of crossborder M\&As, as with every international acquisition an acquirer gains valuable insight that assists with their future acquisitions (Haleblian, Kim, and Rajagopalan, 2006). I measured international acquisition experience as the number of cross-border M\&As completed in the four years prior to the focal acquisition (e.g. Ellis et al., 2011). I also controlled for acquirer and target relatedness, since by acquiring a target firm from the same or a similar industry, an acquirer may be able to more easily integrate their knowledge and routines (Haleblian \& Finkelstein, 1999). This variable was 
operationalized as a dummy variable set equal to "1" if the acquirer and target firms had the same 3-digit SIC codes. Finally, I also controlled for board size (e.g. Kroll et al., 2008), measured as the total number of directors on the acquiring firm's board in a given year.

\section{RESULTS}

To test my hypotheses, I utilized OLS regression with robust standard errors to account for dependence among clustered observations. Table 2.1 presents the descriptive statistics and correlations for the full sample of 552 cross border M\&As. There are several significant correlations at a moderate level, but no correlation is reported above 0.30 , well below the commonly used cut-off of 0.70 (Tabachnick \& Fidell, 2007). Collinearity diagnosis indicates that the mean variance inflation factor (VIF) is 1.76 and the highest individual score is 2.21 , which is far below the commonly used threshold of 10 (e.g. Hair, Anderson, Tatham, \& Black, 1998). Therefore, no issue with multicollinearity was diagnosed. 
TABLE 2.1: Descriptive statistics and correlations

\begin{tabular}{|c|c|c|c|c|c|c|c|c|c|c|c|}
\hline Variables & mean & s.d. & 1 & 2 & 3 & 4 & 5 & 6 & 7 & 8 & 9 \\
\hline $\begin{array}{ll}\text { 1. } & \text { CAR } \\
& {[-3,+3]}\end{array}$ & -0.11 & .14 & & & & & & & & & \\
\hline $\begin{array}{l}\text { 2. Change } \\
\text { in ROA }\end{array}$ & -0.04 & .22 & .04 & & & & & & & & \\
\hline $\begin{array}{l}\text { 3. Relative } \\
\text { acq size }\end{array}$ & 1.55 & .89 & $.09^{*}$ & .06 & & & & & & & \\
\hline $\begin{array}{ll}\text { 4. } & \text { Acq } \\
& \text { relatedn } \\
\text { ess }\end{array}$ & 0.46 & .49 & .07 & $.09 *$ & .01 & & & & & & \\
\hline $\begin{array}{l}\text { 5. Acq } \\
\text { firm } \\
\text { experien } \\
\text { ce }\end{array}$ & 2.77 & 4.3 & $.11^{*}$ & .05 & -.06 & -.01 & & & & & \\
\hline 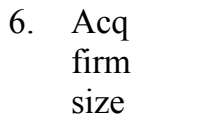 & 9.30 & 1.1 & $.09^{*}$ & $.12 *$ & $.18^{*}$ & .06 & $.27^{*}$ & & & & \\
\hline $\begin{array}{l}\text { 7. } \begin{array}{l}\text { Board } \\
\text { size }\end{array}\end{array}$ & 10.86 & 2.5 & .05 & $.13 *$ & .02 & $.12 *$ & .02 & $.22 *$ & & & \\
\hline $\begin{array}{ll}\text { 8. } & \text { Board } \\
\text { capital } \\
\text { depth }\end{array}$ & 5.75 & 6.1 & $.11^{*}$ & .02 & .07 & .03 & -.02 & $.10^{*}$ & $.13^{*}$ & & \\
\hline $\begin{array}{ll}\text { 9. } & \text { Board } \\
\text { capital } \\
\text { breadth }\end{array}$ & 1.98 & 3.4 & .08 & $.14^{*}$ & $.09^{*}$ & .01 & .00 & .06 & $.12 *$ & -.02 & \\
\hline $\begin{array}{l}\text { 10. Internal } \\
\text { social } \\
\text { ties }\end{array}$ & 0.18 & .22 & $.13^{*}$ & .05 & -.03 & -.03 & -.03 & $-.08 *$ & $-.09 *$ & -.00 & .03 \\
\hline
\end{tabular}

Table 2.2 presents a series of models testing the hypotheses regarding the effect of board capital and internal social ties on value capture. This table provides the results for these hypotheses employing -3 to +3 day CARS as the dependent variable. While I do not report the results for -5 to +5 day CARs, the results were qualitatively similar to those employing -3 to +3 CARs. Table 2.3 provides the results for the hypotheses involving board capital, social ties, and value creation. For both tables, model 1 introduces only control variables and serves as a baseline. The direct effects, namely the effect of board capital breadth and depth on value capture and creation, are introduced in 
Model 2. The full model, including hypothesized interaction effects, is represented by model 3. 
TABLE 2.2: Regression estimates for value capture

\begin{tabular}{|l|ccc}
\hline Variables & Model 1 & Model 2 & Model 3 \\
\hline Relative acquisition size & $0.026^{+}$ & $0.026^{+}$ & 0.013 \\
& $(0.014)$ & $(0.015)$ & $(0.014)$ \\
Acquisition relatedness & 0.017 & 0.010 & 0.013 \\
& $(0.032)$ & $(0.032)$ & $(0.031)$ \\
Acquiring firm int'l & $0.040^{* *}$ & 0.038 & 0.033 \\
experience & $(0.017)$ & $(0.028)$ & $(0.026)$ \\
Acquiring firm size & $-0.012^{* *}$ & $-0.014^{* *}$ & $-0.010^{* *}$ \\
Acquiring firm industry & $(0.004)$ & $(0.004)$ & $(0.004)$ \\
Board size & Included & Included & Included \\
& & -0.210 & -0.199 \\
Board capital depth & $(0.338)$ & $(0.339)$ & $(0.339)$ \\
Board capital breadth & & $0.039^{* * *}$ & $0.041^{* * *}$ \\
Social ties & & $(0.002)$ & $(0.006)$ \\
Depth * Social ties & & 0.010 & $-0.035^{*}$ \\
& & $(0.007)$ & $(0.017)$ \\
Breadth * Social ties & & $0.153^{+}$ & $0.141^{+}$ \\
& & $(0.087)$ & $(0.095)$ \\
& & & $0.021^{* * *}$ \\
R-squared & & & $0.006)$ \\
N & & & 0.001 \\
& & & $(0.002)$ \\
& & & $0.07^{* * *}$ \\
\hline
\end{tabular}

$\mathrm{N}=552$ observations. Standard errors are in parentheses. All models include a constant. $* \mathrm{P}<0.05$

$* * \mathrm{P}<0.01$

$* * * \mathrm{P}<0.001$ 
TABLE 2.3: Regression estimates for value creation

\begin{tabular}{|c|c|c|c|}
\hline Variables & Model 1 & Model 2 & Model 3 \\
\hline Relative acquisition size & $-0.026^{+}$ & $-0.026^{+}$ & -0.013 \\
\hline Acquisition relatedness & $\begin{aligned}(0.014) \\
0.017\end{aligned}$ & $\begin{array}{c}(0.015) \\
0.010\end{array}$ & $\begin{array}{c}(0.014) \\
0.013\end{array}$ \\
\hline & $(0.032)$ & $(0.032)$ & $(0.031)$ \\
\hline $\begin{array}{l}\text { Acquiring firm int'l } \\
\text { experience }\end{array}$ & $\begin{array}{l}-0.004 \\
(0.027)\end{array}$ & -0.010 & -0.013 \\
\hline Acquiring firm size & $0.012 * *$ & $0.014^{* *} *$ & $0.010 * *$ \\
\hline Acquiring firm industry & Included & Included & Included \\
\hline Board size & -0.228 & -0.210 & -0.199 \\
\hline Board capital depth & & $\begin{array}{c}(0.359) \\
0.020\end{array}$ & $\begin{array}{c}(0.339) \\
0.001\end{array}$ \\
\hline & & $(0.014)$ & $(0.002)$ \\
\hline Board capital breadth & & $0.040^{*}$ & $0.035^{*}$ \\
\hline Social ties & & $(0.017)$ & $(0.017)$ \\
\hline & & $(0.087)$ & $(0.091)$ \\
\hline Depth * Social ties & & & 0.019 \\
\hline Breadth $*$ Social ties & & & $\begin{array}{c}0.018 * * * \\
(0.003)\end{array}$ \\
\hline R-squared & $0.062 * *$ & $0.072 * *$ & $0.133 * * *$ \\
\hline
\end{tabular}

$\mathrm{N}=552$ observations. Standard errors are in parentheses. All models include a constant. $* \mathrm{P}<0.05$

$* * \mathrm{P}<0.01$

$* * * \mathrm{P}<0.001$

Hypothesis 1 predicted that board capital depth would be associated with higher value capture from cross-border M\&As. The coefficient in model 2 of table 1 is positive and significant, thus providing support for this hypothesis $(\mathrm{B}=0.039$; $\mathrm{p}$-value $<0.001)$. Hypothesis 2 predicted a positive relationship between board capital breadth and value creation. The significant, negative coefficient for in model 2 of table $2(B=0.040 ; p-$ value $<0.05$ ) indicates support for this hypothesis. Finally, hypothesis 3 predicted that internal social ties would positively moderate both of the aforementioned relationships. Regression coefficients for these interactions, seen in model 3 of tables 1 and 2, also provide strong support for hypothesis 3. 


\section{DISCUSSION AND CONCLUSION}

Integrating resource dependence theory with insights from social-psychological research on boards, I explored in this study how boards contribute to the capture and creation of value from cross-border M\&As. I argued and found that different forms of board capital are important at different phases of the M\&A process, and thus contribute differently to the overall success of the M\&A. Specifically, I found evidence that boards with greater depth of international capital are associated with value capture, suggesting that deep, market-specific knowledge makes an important contribution to pre-deal processes. I also found that boards with greater breadth of international capital are associated with value creation, suggesting that breadth is more important during the postdeal integration phase. Further, I found that both of these relationships were positively moderated by the presence of internal social ties. This suggests that while board expertise is important to cross-border M\&As, the extent to which boards are able to leverage this expertise is dependent upon social-psychological factors.

The findings of this study have important implications for scholarly research in the area of corporate governance. While corporate governance researchers have long argued that directors' characteristics influence firm outcomes, very few board studies have explored the effect of board capital on M\&A performance. Additionally, while resource dependence scholars have acknowledged that boards with relevant knowledge and expertise should be more effective in providing useful advice and counsel to the firms (e.g. Carpenter \& Westphal, 2001; Haynes \& Hillman, 2010), very few studies have attempted to clarify the boundary conditions under which certain forms of board capital 
have stronger or weaker effects on firm-level performance outcomes (Kor \& Sundaramurthy, 2009; McDonald et al., 2008).

By deconstructing the "board capital" construct into breadth and depth components, and by integrating insights from social-psychological literature, I sought in this study to clarify the conditions under which specific forms of board capital can fill the voids of firms lacking the resources needed to successfully execute a particular strategy. The findings of this study demonstrate that since different phases of the cross-border M\&A process involve distinct challenges requiring distinct knowledge and experience, the nature and form of boards' human capital will become more or less important depending upon the specific strategic needs of the firm. I believe that future research that takes such a refined, multitheoretical approach to studying the effect of board capital on performance outcomes will also be valuable.

The findings of this study also provide important practical implications for firms interested in expanding into international markets via cross-border M\&As. Despite the increasing popularity of cross-border M\&As, these transactions fail on average to bring value to acquiring firms. The findings of this study suggest that to the extent that firms receive advice and counsel from directors rich in relevant capital, favorable M\&A outcomes can be realized. Further, firms should be aware of the team dynamics of the board, as the extent to which the board is cohesive may affect directors' ability and willingness to share their expertise during both the pre-deal and post-deal phases of the transaction.

In spite of its contributions, like any study this one has several limitations. Perhaps the most obvious limitation is that I focus only on large, US firms. Although this 
context was appropriate for this study in many regards, it would be interesting for future researchers to investigate whether these findings hold in other country contexts and for smaller firms. Additionally, my empirical approach does not permit a direct examination of the cognitions and social-psychological process hypothesized in these relationships. This limitation is shared by most empirical research on boards, as primary data on boards are notoriously difficult to access (Johnson et al., 2013). However, future research, particularly qualitative research, that can shed further insight into these mechanisms and how they work, would be fruitful. 


\section{ESSAY 3: INTERNATIONAL BOARD CAPITAL AND MNE PERFORMANCE: THE MODERATING EFFECTS OF INTERNATIONALIZATION SCALE AND SCOPE}

\section{INTRODUCTION}

Researchers have long recognized that directors with different characteristics bring unique knowledge, skills, and experiences to a board (e.g. Kor \& Sundaramurthy, 2009). However, despite decades of scholarly research and dialogue, no consensus has emerged regarding the director characteristics that best enable boards to have a positive impact on firm-level performance outcomes. Resource dependence theory suggests that certain board characteristics shape their ability to provide crucial resources to firms such as advice and counsel, information channels, preferential access to external resources, and legitimacy (e.g. Pfeffer \& Salancik, 1978). These strategic resources, in turn, should positively affect firm performance by enabling firms to effectively execute their strategies. The resources that boards provide are especially important when it comes to complex, resource-intensive strategies (e.g. Westphal \& Fredrickson, 2001). Internationalization is a prominent example of a very complex and resourceintensive strategic process for which board capital may prove especially useful. Internationalization is defined as the "strategy through which a firm expands the sales of its goods or services across the borders of global regions and countries into different geographic locations or markets" (Hitt, Ireland, \& Hoskisson, 2007: 251). While internationalization presents a number of potential benefits to firm, it also presents a number of challenges that often impede firms' ability to realize these benefits. As 
internationalization presents a number of unique obstacles to multinational enterprises (MNEs), these firms will likely look to directors with relevant knowledge, expertise, and social capital when expanding into new foreign markets for help formulating and implementing effective internationalization strategy. Yet, while a few notable empirical studies examine how boards help shape firms' internationalization strategies (e.g. Datta, Musteen \& Hermann, 2009; Tihanyi, Johnson, Hoskisson, \& Hitt, 2003), the influence of board capital on the success of firms' internationalization has received relatively little attention in the literature. As a result, we possess very little knowledge about the forms of board capital firms leverage in the internationalization process and how this affects their resultant performance.

In this study, I seek to shed light on this issue by integrating insights from the internationalization literature with resource dependence theory to build and test theoretical arguments regarding board capital, internationalization, and MNE performance. While several studies have examined how certain intangible resources, such as marketing assets and technological capabilities, can be exploited in a way that offsets the costs associated with "foreignness", my study examines resources that actually help firms overcome or mitigate these liabilities of foreignness and newness to begin with. Specifically, I argue that boards' relevant human and social capital can provide the necessary resources to address the challenges associated with operating in foreign markets.

Rather than taking board capital as a composite variable, I take a more refined approach by looking at specific forms of international capital as proxies for different resources and examining how these resources play a more important role depending on 
the scale and scope of firms' international expansion. Since firms at different stages of international expansion face different challenges, I argue that scale of internationalization moderates the effect of board capital on firm performance. More specifically, I argue that since firms in earlier stages of expansion often lack market knowledge and legitimacy, board capital in the form of local networks, international prominence, and depth of experience will be more important at these stages of expansion. I further argue that breadth of international experience is more important at later stages of expansion, when firms tend to lack the ability to manage such complex operations. I also argue that for firms with a broader scope of internationalization (i.e. operate subsidiaries in many countries), breadth of international experience will be more important.

This study makes several important theoretical and managerial contributions. First, I extend resource dependence theory by answering the recent call from scholars to further refine the theory by disentangling the types of human/social capital needed on the board to provide its proposed benefits (Hillman, Withers, \& Collins, 2009). By teasing out the effects of specific forms of capital on performance, this study adds to resource dependence theory and the board capital literature by considering how the context of directors' human and social capital in providing them with relevant resources to effectively govern firms' international strategy. In so doing, this study contributes to a more complete understanding of the role of boards in firms and how they affect strategic actions and outcomes. This study also adds to the longstanding academic conversation on internationalization by examining firm-specific factors that drive the multinationality and performance relationship. Further, I provide a more complete theoretical treatment of the internationalization construct by simultaneously examining different stages and 
components of the internationalization process (i.e. scale and scope). In taking a refined, dynamic approach to understanding the internationalization process, I seek to elucidate the strategies and resources firms can employ to overcome the challenges and costs of internationalization. Finally, this study provides practical guidance to managers of MNEs by elucidating the optimal composition of boards for firms at different stages of internationalization.

The remainder of this manuscript proceeds as follows. First, I review the relevant literature on the resource provision role of boards as well as internationalization. Next, I develop hypotheses delineating the effects of different forms of international board capital on MNE performance at various stages of the internationalization process. I then elaborate on the data sources and methodology employed to test these hypotheses. Finally, I present and discuss the results of the statistical analyses and provide concluding remarks.

\section{LITERATURE REVIEW}

\section{Resource Dependence Theory}

While the monitoring role of boards has traditionally dominated the literature on boards (e.g. Fama \& Jensen, 1983; Jensen \& Meckling, 1976), resource dependence theory provides an alternative view of boards as mechanisms through which firms access important resources from the external world (e.g. Pfeffer \& Salancik, 1978). Resource dependence theory views firms as open systems, dependent on external organizations and environmental contingencies (Pfeffer \& Salancik, 1978; Lynall, Golden, \& Hillman, 2003). This dependency creates risk and uncertainty, which in turn affects performance. 
Accordingly, a firm's survival and performance depends on its ability to acquire essential resources from the external environment (Pfeffer \& Salancik, 1978; Wernerfelt, 1984).

Resource dependence theory proposes that boards are a mechanism for managing external dependencies and reducing environmental uncertainty (Pfeffer, 1972). Boards play a crucial role in helping firms to manage this external dependence by providing critical strategic resources as well as linkages to audiences that provide or mediate access to resources (Lynall, Golden, \& Hillman, 2003). Thus, by having directors who serve to link the organization with its external environment, a board may act to reduce uncertainty and increase performance. Among the most critical resources provided by boards are: advice and counsel to the firm on substantial matters such as strategy formulation, access to information outside the firm, preferential access to valuable resources through personal connections, and legitimacy (Pfeffer \& Salancik, 1978).

Boards leverage their social and human capital to help them provide these resources. Board capital, a construct that represents the composite of the human and social capital of the board, is intended to capture the ability of the board to provide resources to the firm (Hillman \& Dalziel, 2003). Boards with higher levels of certain forms of capital should be able to serve their resource provisional roles more effectively than others with regard to corresponding strategies and subsequent performance (Haynes \& Hillman, 2010). While board capital is a relatively new term in the management literature, the proposition that boards use their human and social capital to provide resources to firms has received a great deal of empirical support over the years. Indeed, resource dependence theory has received more empirical support than any other theoretical lens applied to board research, including agency theory (Davis \& Cobb, 2010; 
Hillman, Withers, \& Collins, 2009; Johnson, Ellstrand, \& Daily, 1996). Thus, examining how boards use their human and social capital to provide strategic resources to firms has proven a fruitful venue for understanding the function of boards.

Human capital refers to directors' innate and learned abilities gained through education, training, and work experience (Becker, 1975; Sundaramurthy, Pukthuanthong, $\&$ Kor, 2013). A great deal of extant research has examined the role of boards' human capital in providing the resources proposed by resource dependence theory. With regard to the provision of advice and counsel, boards' human capital, namely educational background, occupation, and work experience, has been consistently linked with firms' strategic behavior. This suggests that directors' knowledge and experiences shape the advice and counsel they provide to firms, which in turn influences firms' strategic actions. A few studies have found that directors' educational background affects the manner in which they advise and counsel firms. For instance, Dalziel, Gentry, and Bowerman (2011) find that firms invest more in research and development when their boards have higher representation from Ivy League institutions (where the benefits of research are strongly promoted).

While relatively few studies have linked boards' educational background with their provision of advice and counsel, there are far more studies that explore the effect of directors' occupation and work experience on firm behavior. For example, Stearns and Mizruchi (1993) find that the types of financial institutions represented on a board affect the financing the firms obtain, suggesting that directors' occupation frames the strategic advice they provide to firms. Golden and Zajac (2001) find that boards with a large degree of occupational heterogeneity are positively associated with strategic change, 
suggesting that diversity in directors' experiences and expertise give them a broader variety of strategic options with which to advise firms. In addition to team-level occupational heterogeneity, the representation of certain types of occupations amongst directors has also been linked with the provision of important advice and counsel. For instance, both Hillman (2005) and Lester and colleagues (2008) find evidence that government officials on the board can provide unique advice and counsel regarding the public policy process. This is valuable to firms because this type of advice if often very expensive or difficult for a firm to obtain due to the complexity of this process. Other studies have found evidence that directors with relevant experience in a particular industry (e.g. Kroll, Walters, \& Wright, 2008) or with a particular strategic behavior such as acquisitions (e.g. McDonald et al., 2008) provide superior advice and counsel, which in turns leads to superior firm performance. Thus, there is a great deal of empirical evidence to support the claim that boards' human capital, particularly relevant occupation and work experience, provide them with the ability to provide firms with superior advice and counsel on important strategic matters.

Social capital refers to directors' socially valuable attributes (Johnson, Schnatterly, Bolton, \& Tuggle, 2011) as well as their ability to access information and resources through their social relationships and networks (Kor \& Sundaramurthy, 2009; Nahapiet \& Ghoshal, 1998; Sundaramurthy et al., 2013). Extant research has found that directors' social capital is particularly useful in providing access to information channels. Two of the most important forms of boards' social capital are social ties and prestige (Johnson et al., 2011). The most commonly studied form of boards' social ties is the interlock, which occurs when a director one firm's board sits on the board of another. 
Interlocks provide a forum for the corporate elites of multiple firms to meet and discuss issues of strategic relevance, giving directors the opportunity to learn about novel experiences and insights and bring this information back to the focal firm (Mizruchi, Stearns, \& Marquis, 2006). This allows directors to serve as conduits of information between the firm and important external constituents, carrying and delivering important information about strategies, practices, and performance. Existing research has linked board interlocks with a wide range of firm behaviors, including corporate philanthropy (e.g. Galaskiewicz \& Wasserman, 1989), mergers and acquisitions (e.g. Haunschild, 1993), adoption of takeover defense strategies (e.g. Davis, 1991), adoption of new organizational structures (Palmer et al., 1993), political contributions (e.g. Mizruchi, 1992), private equity deals (Stuart \& Yim, 2010) and the successful expansion into new, emerging markets (Connelly, Johnson, Tihanyi, \& Ellstrand, 2011).

In addition to providing access to novel information from the outside world, boards can also provide access to critical strategic resources through their social capital. Mizruchi and Stearns (1994) argue that directors who work at financial institutions may not only provide advice regarding external financing, but also may serve as an important facilitator of these funds in tight capital markets. Provan, Beyer, and Kruytbosch (1980) find that links with the community, including board influence within the community, is a significant predictor of potential power that firms gain over resource providers. In a related study, Provan (1980) found that board prestige within the community was associated with increased fundraising ability for firms. Another group of studies has explored how having well-known, powerful directors such as government officials help firms to gain necessary resources from the political environment (e.g. Hillman, 2005; 
Lester et al., 2008). Thus, empirical evidence suggests that boards with prestigious, powerful directors with high levels of social capital are able to help firms acquire critical resources from the external environment.

Finally, boards' social capital can also provide firms with legitimacy and credibility. Legitimacy is important to firms because it connects them with key stakeholders on whom these firms depend for resources and survival (Arthaud-Day, Certo, Dalton, \& Dalton, 2006; Pfeffer \& Salancik, 1978). Stakeholders consider legitimate firms to be those that embody prevailing social norms and values (Suchman, 1995). This legitimacy leads stakeholders to trust and support these firms more than nonlegitimate firms (Arthuad-Day et al., 2006). Boards' social capital can play an important role in providing firms with legitimacy. Certo (2003), for instance, finds that prestigious boards improve firms' legitimacy and subsequent IPO performance. Kassinis \& Vafeas (2002) find that the likelihood of a lawsuit decreases with the number of directorships held by outside directors, suggesting more reputable directors act to prevent environmental litigation. Directors can also negatively affect firms' legitimacy when their social capital has been damaged or compromised, which may lead firms to dismiss directors in order defend themselves against legitimacy loss and maintain the support of key stakeholders (Arthaud-Day, Certo, Dalton, \& Dalton, 2006; Cowen \& Marcel, 2011). Thus, there is considerable evidence to suggest that the prestige and social ties of boards can improve the legitimacy of firms, which in turn has an important effect on firm performance.

Taking the aforementioned findings together, boards' human capital appears to have an important effect on the provision of advice and counsel, while social capital 
affects more their ability to provide access to information, strategic resources, and legitimacy with key stakeholders. While these studies have provided a number of important insights, there remains a great deal of work to be done in order to fully understand the resource provision role of boards.

One key deficiency of the extant literature is the lack of refinement in the consideration of specific director characteristics that allow directors to effectively execute the four resource provision functions. Few empirical studies have attempted to delineate the nature and sources of board capital that might be linked to the relative success of specific firm strategic actions. Thus, insufficient attention has been given to the boundary conditions under which specific forms of board capital might have stronger or weaker effects on performance outcomes (McDonald et al., 2008). Accordingly, there is a great deal of room for clarification and refinement in the literature with regard to understanding how specific forms of board capital can serve to fill the voids of firms lacking the resources needed to successfully execute a particular strategy.

\section{Internationalization}

Expanding and managing international operations in diverse country markets have become necessary strategic issues for firms competing in today's global marketplace (Hitt, Tihanyi, Miller, \& Connelly, 2006). Management scholars view internationalization as an important and promising strategy for seeking sustainable competitive advantage (Nachum \& Zaheer, 2005). Many potential advantages of internationalization have been outlined in the literature including the ability to exploit economies of scale and scope (Hitt, Hoskisson, \& Kim, 1997; Kogut, 1985), access to cheaper and/or superior resources, (Contractor, Kundu, \& Hsu, 2003), and increased market power (Kim, Hwang, 
\& Burgers, 1993). Internationalization can serve as a vehicle for substantial growth by providing firms with the opportunity to access new markets, share unique firm capabilities across business units, and exploit differences in factor prices across locations (Porter, 1990). Additionally, firms can reduce systematic portfolio risk by expanding into countries with asynchronous business cycles and obtaining access to diverse sets of currencies (Contractor, 2007; Rugman, 1976). Thus, there are many reasons why a positive relationship between internationalization and firm performance should be expected.

On the other hand, internationalization is a tremendously complex and risky process. The internationalization process is often accompanied by large commitments of resources (Contractor et al., 2003), and the "liabilities of foreignness", a term that represents firms' unfamiliarity with the local market, a lack of information networks or political influence in the host country, and the foreign firm's inability to appeal to nationalistic buyers (Zaheer, 1995). These costs can offset any benefits firms gain through expanding their international operations. Internationalization, therefore, is not a guaranteed "win" for firms, as there are also numerous costs and risks that firms incur as they increase their international operations (Thomas \& Eden, 2004).

The complexities and uncertainties associated with internationalization may be reflected in the mixed empirical evidence to date. While some studies have found a positive, linear relationship between internationalization and performance (e.g. Denis, Denis, \& Yost, 2002; Han et al., 1998), others have found a negative (e.g. Brewer, 1981; Collins, 1990) or even nonsignifcant (e.g. Morck \& Yeung, 1991) relationship. Some scholars have attempted to reconcile these mixed findings by exploring the possibility 
that the reason for the equivocal findings was that the relationship between internationalization and performance was actually curvilinear. Some studies hypothesize a "u-shaped" relationship, in which firms experience an initial downturn in performance as they overcame the liabilities of foreignness, but then at some point reach an inflection point at which the benefits of internationalization are realized and the relationship becomes positive (e.g. Lu \& Beamish, 2001; Ruigrok \& Wagner, 2003).

Other studies, however, propose an "inverted u-shape" relationship between internationalization and performance, in which firms experience a positive relationship early on in their internationalization process, but later experience a downturn in performance due to the increasing complexities of managing highly internationalized operations straining firm resources and managerial capacity (e.g. Gomes and Ramaswamy, 1999; Hitt et al., 1997). More recent research has attempted to reconcile previous research by proposing that the relationship between internationalization and performance actually followed a sigmoid-shaped or "s-curve" pattern (e.g. Contractor, Kundu, et al., 2003; Lu \& Beamish, 2004). Despite these developments, empirical evidence of a universal relationship between internationalization and performance remains limited.

Taking a different approach to reconciling these mixed findings, another group of studies emphasizes the importance of intangible resources in facilitating performance as firms expand internationally (e.g. Delios \& Beamish, 1999; Goerzen \& Beamish, 2003; Rugman \& Sukpanich, 2006). Taking an internalization theory perspective, the core argument of these studies is that intangible resources can provide ownership advantages that lend themselves to internal control and expansion into new geographic markets (Hitt 
et al., 2006). The findings from this research provide evidence that proprietary, intangible resources such as technological know-how and marketing capabilities can be leveraged to generate rents that offset the inherent costs of internationalization. Yet, because the key constructs used in the vast majority of these studies are very rough proxies for limited set of firm capabilities (i.e. R\&D intensity, advertising intensity, firm size), we still have a relatively limited understanding of which resources facilitate performance for firms as they expand internationally. Additionally, given that much internationalization research has emphasized the challenges associated with doing business abroad, it is surprising that very few studies have attempted to explore which intangible resources may help firms overcome these costs in the first place. Thus, we currently possess a limited conception of what constitutes valuable intangible resources for MNEs that could help facilitate competitive advantage through internationalization.

This study contributes to this literature by exploring how the resources provided by boards' relevant human and social capital may help MNEs overcome the challenges of internationalization. A few studies have attempted to explore the role of boards in the firm internationalization process (e.g., Carpenter, Pollock, \& Leary, 2003; Connelly, Johnson, Tihanyi, \& Ellstrand, 2011; Datta, Musteen, \& Hermann, 2009). These studies reflect the growing recognition that given the complexities associated with international expansion and the considerable challenges that firms face in achieving desired outcomes, boards should play an important role in effective internationalization. Still, very few studies have explored how board capital affects firms' ability to ultimately experience performance gains from international expansion. This study contributes to the literature 
by exploring how specific forms of board capital can provide the necessary resources for firms to overcome the challenges of internationalization and expand successfully.

Additionally, I simultaneously examine how the scale and scope of firms' internationalization strategies affect the relationship between board capital and firm performance. All internationalization is not created equal, and firms at different stages of internationalization face different challenges requiring different resources. Board capital comes in many forms, and these diverse forms of capital may be more or less important depending on the stage of internationalization at which the firm is operating. Whereas scale represents the extent of firms' penetration of and dependence on foreign markets (Thomas \& Eden, 2004), scope reflects the geographic dispersion of operations across countries (Hitt et al., 2006). Focusing solely on one dimension of internationalization may not fully reflect the extent of international expansion (Hitt et al, 2006). As scale and scope measure two distinct forms of internationalization, accompanied with their own unique strategic motives and operational challenges, it is important to consider both separately and simultaneously to fully explore firms' internationalization strategies. Thus, I attempt in this study to isolate the effects of both scale and scope of internationalization on firms' ability to leverage board capital to achieve superior performance.

\section{HYPOTHESES}

\section{International Board Capital and MNE Performance}

Board capital refers to the sum of human and social capital of the board of directors, and is a proxy for the board's ability to provide resources to the firm (Hillman \& Dalziel, 2003). Board capital can help directors to provide firms with useful advice and counsel on important strategic matters, as well as linkages to important business contacts, 
legitimacy, and access to communication channels and valuable resources. The strategic resources provided by board capital are particularly important when firms engage in risky, uncertain, and complex strategic action, such as internationalization. All of the aforementioned resources can play an important role in helping firms overcome the challenges associated with internationalization, thereby facilitating superior performance.

Board capital comes in many diverse forms and can serve as the basis upon which directors provide an array of strategic resources. Recent research has distinguished between depth and breadth dimensions of boards' human capital. Board capital depth refers to the profundity of directors' expertise, knowledge, skills, and social networks, and suggests embeddedness in a particular field, industry, or environment (Haynes \& Hillman, 2010; Lester et al., 2008). In the case of international board capital, depth refers to deep knowledge of a foreign market that stems from the embeddedness associated with having origin or education in that market, or from having spent many years in the market through international work assignments. Breadth of internationalization, conversely, refers to the extent of the directors' relevant skills, knowledge, and expertise. Directors would gain breadth of international capital by having a broad scope of international experience across an array of foreign markets.

Among the most important resources boards provide to firms is advice and counsel regarding strategic actions (Pfeffer \& Salancik, 1978). Directors with depth of international experience will have gained a great deal of market-specific knowledge that firms can leverage as they expand their global footprint into particular markets and regions. Directors with breadth of international experience, on the other hand, may not have a great deal of market specific knowledge, but they will have gained a "global 
mindset" that will be helpful in providing excellent advice and counsel. This global mindset provides directors with an awareness and openness to the diversity of cultures and markets, and an inclination and capability to integrate across the diversity. This breadth of experience helps directors gain broad skill sets and increased cognitive complexity, upon which they can draw when offering strategic advice to firms undergoing the internationalization process (Gregersen et al., 1998; Lovvorn \& Chen, 2011; Morrison et al., 1999). Thus, directors with a breadth of international experience will excel at developing creative solutions to issues related to internationalization.

In both cases, these directors will have valuable human capital that will allow them to effectively serve their role as advisors and counselors with regard to international strategy. Thus, I predict:

Hypothesis 1a: Boards' depth of international experience is positively associated with firm performance.

Hypothesis $1 \mathrm{~b}$ : Boards' breadth of international experience is positively associated with firm performance.

In addition to human capital, boards' social capital can also provide a number of important resources to firms that may prove beneficial in the internationalization process. One such important resource that boards provide to firms is legitimacy with important external actors (Pfeffer \& Salancik, 1978). Directors with relevant international social capital, stemming from international prestige or from holding directorships with local firms in the host market, will be able to provide the focal firm with additional legitimacy with important actors and consumers in the host country. Through their social capital, 
directors develop relationships with important players, including suppliers, distributors, and major customers (Kor \& Sundaramurthy, 2009). With this social capital, directors can help the firm acquire critical resources, gain legitimacy, and initiate new business relationships essential for growth (Hillman \& Dalziel, 2003; Kor \& Sundaramurthy, 2009; Pfeffer \& Salancik, 1978). Therefore, the increased legitimacy and connectedness provided by boards' international social capital should have a positive effect on firm performance. I therefore predict:

Hypothesis 1c: Boards' international social capital is positively associated with firm performance.

\section{Scale of Internationalization}

While international board capital in all three forms (depth, breadth, and social capital) should be beneficial to MNEs, the relative importance of each form of capital should change as these firms enter different stages of internationalization. MNEs face different challenges depending on the unique configuration of their international operations. Firms vary greatly with regard to their scale, or depth, of internationalization. As firms increase their scale of internationalization, they will accordingly need different resources at each stage to help mitigate the distinct challenges posed. One of the key challenges for firms in early stages of internationalization is the lack of host market knowledge (e.g. Contractor et al., 2003; Lu \& Beamish, 2004). Firms at early stages of internationalization incur large learning costs because of unfamiliarity with foreign markets, cultures, and environments (Contractor et al., 2003; Johanson \& Vahlne (1977). These costs can often offset any potential benefits associated with internationalization. 
An additional challenge that firms at early stages of internationalization face is the lack of legitimacy in the host market. As firms expand abroad, not only do managers lack knowledge about operating in the foreign environment, but they also tend to lack external business networks, political connections, and recognition and reputation with local consumers. These challenges can put firms at a disadvantage vis-à-vis established, domestic firms, thus decreasing these firms' competitiveness (Lu \& Beamish, 2004).

To the extent that firms possess important resources to mitigate these liabilities of foreignness and newness, they should be able to attain greater financial performance. With regard to market knowledge, directors with depth of international experience in the target market can serve as an important resource by advising the firms on how to effectively build operations in the new market. The social capital of directors stemming from local networks and prestige may help firms build legitimacy, facilitate access to critical resources, and help firms initiate new business relationships (Hillman, 2005; Kor \& Sundaramurthy, 2009; Pfeffer, 1972). Thus, directors with relevant international social capital can provide important linkages with important actors in the new market and build legitimacy with consumers. I therefore predict:

Hypothesis 2a: The relationship between boards' depth of international capital and firm performance is moderated by scale of internationalization such that depth has a stronger relationship with performance at earlier stages of internationalization.

Hypothesis 2b: The relationship between boards' international social capital and firm performance is moderated by scale of internationalization such that social 
capital has a stronger relationship with performance at earlier stages of internationalization.

On the other hand, firms at later stages of internationalization face challenges related to increased operational complexity. As firms continue to expand abroad, the growth of coordination and governance costs often begin to exceed the benefits of further internationalization, due to the complexity of international operations (Contractor et al., 2003; Gomes \& Ramaswamy, 1999). Dissimilarities in language and the business environment, geographic distance, governmental policies that favor domestic firms, and the ambiguity of environmental factors all contribute significantly to the increased information processing demands on executives (Sanders \& Carpenter, 1998; Tihanyi \& Thomas, 2005). Executives' limited capacity to cope successfully with greater complexity and processing demands may inhibit the realization of gains from increased internationalization (Grant, 1987). Thus, as firms increase their scale of international operations, managing these complexities can become too difficult for firms to handle effectively.

I contend that board capital breadth is a more beneficial resource for firms at later stages of internationalization with regard to scale, as these directors will have additional information-processing capabilities and cognitive processes that help them arrive at integrative solutions that balance competing country, business, and functional concerns (e.g. Murtha, Lenway, \& Bagozzi, 1998). These directors can provide effective advice and counsel to firms in a way that compensates for executives' deficiencies in cognitive capacity. I therefore predict: 
Hypothesis 2c: The relationship between boards' breadth of international capital and firm performance is moderated by scale of internationalization such that breadth has a stronger relationship with performance at later stages of internationalization.

\section{Scope of Internationalization}

Similar to increased scale of internationalization, firms with a wide scope of internationalization often face challenges due to increasingly complex operations. As the number of different cultural environments the firm has to deal with increases, transaction and governance costs also increase (Contractor et al., 2003; Gomes \& Ramaswamy, 1999). The coordination of operations across disparate host countries significantly increases information-processing demands on a firm's executives and administrative systems (Hitt et al., 1997; Lu \& Beamish, 2004). As firms broaden their internationalization scope, they must deal with the unique features of each individual country, such as national culture, institutions, consumer tastes, suppliers, languages, government relations, and educational systems (Vermeulen \& Barkema, 2002). Thus, higher geographic scope requires firms to manage the complexities of many unique markets, which requires these firms to invest more time and attention than firms operating in a limited number of geographic markets (Vermeulen \& Barkema, 2002). Directors with a global mindset, developed from their breadth of international experience, should also serve as an important resource for firms with a broad scope of internationalization by providing valuable advice and counsel to help navigate the increasingly complex operations. Therefore, I propose: 
Hypothesis 3: The relationship between boards' breadth of international capital and firm performance is moderated by firms' scope of internationalization such that board capital breadth has a stronger relationship with performance at higher levels of scope.

\section{METHODS}

\section{Sample and data}

In order to test these hypotheses, I collected archival data on a panel of US-based S\&P 500 firms observed from 2004-2011, allowing a 1-year lag for all independent variables. As the function and structure of boards vary considerably across country contexts, I utilized a sampling frame that allowed me to limit variance in the outcome variable caused by differences in country-level governance features (e.g. Dalziel et al., 2011). Thus, I eliminated all non-US headquartered firms from the final sample. Firms were also excluded from the sample if data were unavailable for critical variables in the model or if there were less than 2 years of data available during the observation period. Finally, because international board capital should primarily benefit firms with reliance on non-domestic markets, I found it necessary to exclude firms that had no internationalization throughout the observation period. These adjustments resulted in a final sample of 377 firms for a total of 1982 observations.

I utilized a variety of data sources to produce measures of the variables in the model. Directorship listings were obtained for each firm-year observation from Corporate Library in the WRDS database. Data on director characteristics used to construct the independent variables were gathered from a variety of sources including the BoardEx database, firm proxy statements, and popular press coverage from sources such 
as Forbes and Businessweek. Firm-level financial and control variables were collected from the Standard \& Poor's Compustat database. Table 3.1 presents a summary of the key variables used in this study. 
Table 3.1: Key variables for essay 3

\begin{tabular}{lcl}
\multicolumn{1}{c}{ Variables } & Brief Description & \multicolumn{1}{c}{ Sources } \\
$\begin{array}{l}\text { Dependent Variable } \\
\text { Firm Performance }\end{array}$ & 1) Return on Assets & $\begin{array}{l}\text { Compustat, annual } \\
\text { reports }\end{array}$
\end{tabular}

Independent and Moderating Variables

International Board Capital

Firm Internationalization

Control Variables

Firm size, firm age, board size, R\&D intensity, SIC (industry)
1) Breadth: average number of countries in which board members have worked

2) Depth: number of years board members worked in the region

3) Board networks: number of directorships board members have in the region of international expansion.

4) International prominence: the number of board members who are CEOs of Global 500 firms.

1) Scope: number of countries in which firm operates foreign subsidiaries

2) Scale: Foreign Sales/Total Sales
WRDS Corporate Library, BoardEx, Annual reports, BusinessWeek

\section{Dependent variable}

Directory of Corporate Affiliations, Compustat

Financial performance. In selecting the financial performance measure, I considered a number of possible alternatives commonly used in the literature. While MNEs pursue a variety of objectives and goals, it is widely accepted that MNEs are fundamentally concerned with accounting-based results (Bouquet, Morrison, \& Birkinshaw, 2009). Following previous research (Daniels and Bracker, 1989; Ramaswamy, 1995; Gomes and Ramaswamy, 1999), I used return on assets (ROA) to 
measure the performance of MNEs because it represents the resources available for reinvestment in a firm (Subramaniam \& Youndt, 2005) and it measures the efficiency with which assets are employed (Hsu \& Boggs, 2003). Furthermore, ROA is an appropriate proxy for performance due to the relative inability of firm management to manipulate this measure (Gomez-Mejia \& Palich, 1997). Data for this measure were obtained from the Standard and Poor's Compustat database.

\section{Independent and moderating variables}

International board capital. Board capital depth was measured as the total number of years board directors worked in the region(s) of the firm's international operations. I also considered directors' national origin as well as years spent obtaining education in the region in constructing this measure. Board capital breadth was measured as the average number of countries in board members had worked. To measure international social capital, I considered both directors' social ties as well as their prestige/international prominence. I measured social ties as the total number of directorships held in the region of operations by directors. International prominence was measured as a dummy variable, set equal to 1 if the director was the CEO of a Global 500 firm. Board capital data were collected from a variety of sources, including BoardEx, proxy statements, popular press articles and annual reports.

Internationalization scale. Following previous studies (e.g. Denis, Denis, \& Yost, 2002; Kirca et al., 2011; Ruigrok \& Wagner, 2003), I measure internationalization scale as the ratio of foreign sales to total sales (FSTS). FSTS is a common measure of internationalization that captures a firm's foreign market penetration and its monetary or 
revenue dependence on foreign markets (Hsu \& Boggs, 2003; Thomas \& Eden, 2004). This measure was constructed using data from Standard and Poor's Compustat database. Internationalization scope. I operationalize internationalization scope, or breadth of internationalization, as the total number of countries in which a firm operates subsidiaries (e.g. Morck \& Yeung, 1991; Tallman \& Li, 1996). Data for this variable were obtained using the Directory of Corporate Affiliations, and supplemented by the MNEs' annual reports as needed.

\section{Control variables}

I control for the effects of several theoretically relevant variables that might potentially affect the relationships investigated in this study. For instance, product diversification was included as a control variable, as prior research shows that product diversification positively affects firm performance (e.g. Chang \& Thomas, 1989). This variable was calculated using the traditional entropy score approach (Goerzen \& Beamish, 2003; Hitt et al., 1996). I controlled for firms' technological capabilities by including R\&D intensity in the model, as this could be a source of ownership advantages that could affect firm performance (e.g. Goerzen \& Beamish, 2003; Kotabe et al., 2002; Thomas \& Eden, 2004). I also controlled for firm age, as it has also been associated with higher performance. Firm age was measured as the duration of a firm's existence since its year of incorporation. To control for any industry effects, I included dummy variables in the model based on firms' 2-digit SIC code. Finally, I controlled for firm size, as it has been commonly associated with firm performance in prior research (Contractor et al., 2003; Goerzen \& Beamish, 2003) and may provide firms with the ability to more easily 
overcome the advantages of domestic competitors (Caves, 1971; Dastidar, 2009). Firm size is measured as the natural logarithm of firm sales.

\section{Estimation method}

I lagged all explanatory variables and controls by one year relative to the dependent variable in the models in order to facilitate causal interpretation of our findings. While the use of a 1-year lag coupled with my longitudinal research design does help alleviate concerns regarding reverse causality (Benner \& Tushman, 2002), I found it necessary to account for potential endogeneity in the models in order to avoid misspecification due to unobserved factors. I controlled for endogeneity in this study using the two-stage Heckman (1979) procedure. In Stage 1, I obtained the Inverse Mills Ratio by estimating a probit model with multinationality dummy-coded (set equal to 1 if the firm has any foreign sales in a given year) and used as the dependent variable. Then, I included the Inverse Mills Ratio as a regressor in Stage 2, using firm performance as the dependent variable. Including the Inverse Mills Ratio in the stage 2 model removes any potential bias due to endogeneity and sample selection (Hitt et al., 2006; Shaver, 1998).

To estimate Stage 2, I used the generalized estimation equations (GEE) technique. GEE represents a generalization of the generalized linear model (GLM) that can handle repeated measures data, such as panel or cluster data, in a convenient and flexible way (Liang \& Zeger, 1986). GEE is a particularly well-suited technique for modeling panel data, because it measures both within- and between- firm variance and generates robust estimates of standard errors (Ballinger, 2004; Pfarrer, Pollock, \& Rindova, 2010). It is also preferred to other analytical techniques for panel data because it is better able to accommodate different structures of within-group correlations (Gao, 2012). Additionally, 
as GEE is less computationally intensive than other popular panel data analysis techniques, it is generally less subject to instability and convergence issues (Schneper \& Guillen, 2004). GEE has been used frequently in biostatistics and health care research, and is gaining traction in management and international business research (e.g. Chen \& Hambrick, 2012; Flores \& Aguilera, 2007; Ma \& Delios, 2010).

\section{RESULTS}

Table 3.2 presents descriptive statistics and a correlation matrix for the full sample of 377 firms. There are several significant correlations at a moderate level, but no correlation is reported above 0.35 , well below the common used cut-off of 0.70 (Tabachnick \& Fidell, 2007). Collinearity diagnosis indicates that the mean variance inflation factor (VIF) is 2.22 and the highest individual score is 2.71 , which is far below the commonly used threshold of 10 (e.g. Hair, Anderson, Tatham, \& Black, 1998). Therefore, no issue with multicollinearity was diagnosed.

Table 3.3 provides the GEE regression results regarding international board capital, multinationality scale and scope, and firm performance. Table 3.3 includes a total of three models, which were built incrementally. Model 1 serves as the baseline model, and thus introduces only the control variables, namely firm size, firm age, board size, $R \& D$ intensity, industry, and the inverse mills ratio. The direct effects, the effects of international board capital on firm performance, are introduced in Model 2. My full model, including the hypothesized interaction effects between international board capital and firms' internationalization scale and scope, is represented in model 3. 
Table 3.2 Descriptive statistics and correlation matrix

\begin{tabular}{|c|c|c|c|c|c|c|c|c|c|c|c|c|}
\hline Variables & mean & & 1 & 2 & 3 & 4 & 5 & 6 & 7 & 8 & 9 & 10 \\
\hline 1. $\mathrm{ROA}$ & 5.64 & 6.73 & & & & & & & & & & \\
\hline 2. Firm size & 9.30 & 1.17 & $.07 *$ & & & & & & & & & \\
\hline 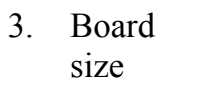 & 10.86 & 2.56 & $.08^{*}$ & $.13^{*}$ & & & & & & & & \\
\hline 4. Firm age & 44.67 & 25.69 & -.04 & .01 & $.15^{*}$ & & & & & & & \\
\hline $\begin{array}{l}\text { 5. } \mathrm{R} \& \mathrm{D} \\
\text { intensity }\end{array}$ & 0.76 & 3.48 & $.08^{*}$ & $.06^{*}$ & .02 & $.12 *$ & & & & & & \\
\hline $\begin{array}{l}\text { 6. } \\
\text { Board } \\
\text { Capital } \\
\text { Depth }\end{array}$ & 5.75 & 6.15 & $.11^{*}$ & .02 & $.07 *$ & -.03 & -.02 & & & & & \\
\hline $\begin{array}{ll}\text { 7. } & \text { Board } \\
\text { Capital } \\
\text { Breadth }\end{array}$ & 1.98 & 3.44 & $.10^{*}$ & .00 & $.09 *$ & .01 & .00 & $-.06^{*}$ & & & & \\
\hline $\begin{array}{ll}\text { 8. } & \text { Board } \\
& \text { Networks }\end{array}$ & 1.88 & 3.42 & $.13^{*}$ & .02 & -.03 & -.03 & $.07 *$ & $.08 *$ & -.04 & & & \\
\hline $\begin{array}{ll}\text { 9. } & \text { Board } \\
& \text { Prestige }\end{array}$ & 0.19 & 0.40 & $.16^{*}$ & .05 & $.09 *$ & .04 & -.02 & .03 & $.06^{*}$ & $.17^{*}$ & & \\
\hline 10. FSTS & 28.53 & 16.99 & $.06^{*}$ & $.15^{*}$ & $.08 *$ & $.08^{*}$ & $.08 *$ & $.15^{*}$ & .04 & $.12 *$ & -.01 & \\
\hline 11. Scope & 7.95 & 6.56 & -.02 & $.10^{*}$ & $.07 *$ & $.10^{*}$ & $.05^{*}$ & .01 & $.10^{*}$ & $.09 *$ & -.00 & $.35^{*}$ \\
\hline
\end{tabular}


Table 3.3 GEE analysis results for the effect of board capital on MNE performance

\begin{tabular}{|c|c|c|c|}
\hline Variables & Model 1 & Model 2 & Model 3 \\
\hline \multicolumn{4}{|l|}{ Control variables } \\
\hline Inverse Mills Ratio & $\begin{array}{c}1.98 * * * \\
(0.33)\end{array}$ & $\begin{array}{c}1.77 * * * \\
(0.35)\end{array}$ & $\begin{array}{l}1.34 * * \\
(0.42)\end{array}$ \\
\hline Firm size (log of sales) & $\begin{array}{c}1.56 * * * \\
(0.30)\end{array}$ & $\begin{array}{l}1.35^{* *} \\
(0.41)\end{array}$ & $\begin{array}{l}1.35^{* *} \\
(0.43)\end{array}$ \\
\hline Firm age & $\begin{array}{l}1.09 * * * \\
(0.24)\end{array}$ & $\begin{array}{l}1.08 * * * \\
(0.27)\end{array}$ & $\begin{array}{c}1.08^{* * *} \\
(0.32)\end{array}$ \\
\hline Board size & $\begin{array}{c}1.02 \\
(0.98)\end{array}$ & $\begin{array}{l}1.03 \\
(0.97)\end{array}$ & $\begin{array}{l}1.15 \\
(0.89)\end{array}$ \\
\hline R\&D intensity & $\begin{array}{l}-0.34 \\
(0.28)\end{array}$ & $\begin{array}{l}-0.26 \\
(0.30)\end{array}$ & $\begin{array}{l}-0.24 \\
(0.32)\end{array}$ \\
\hline \multicolumn{4}{|l|}{$\begin{array}{l}\text { Independent and moderating } \\
\text { variables }\end{array}$} \\
\hline Board capital depth & - & $\begin{array}{c}0.06^{* * * *} \\
(0.01)\end{array}$ & $\begin{array}{c}0.06^{* * *} \\
(0.01)\end{array}$ \\
\hline Board capital breadth & - & $\begin{array}{c}0.03^{* *} \\
(0.01)\end{array}$ & $\begin{array}{c}0.03^{* *} \\
(0.01)\end{array}$ \\
\hline Board local networks & - & $\begin{array}{c}0.09 \\
(0.06)\end{array}$ & $\begin{array}{c}0.07 \\
(0.06)\end{array}$ \\
\hline Board prestige & - & $\begin{array}{c}0.41 * * * \\
(0.07)\end{array}$ & $\begin{array}{l}0.39^{*} \\
(0.18)\end{array}$ \\
\hline Internationalization scale & - & $\begin{array}{l}0.03 * * \\
(0.01)\end{array}$ & $\begin{array}{c}0.02 \\
(0.02)\end{array}$ \\
\hline Internationalization scope & - & $\begin{array}{l}0.05+ \\
(0.03)\end{array}$ & $\begin{array}{c}0.05 \\
(0.06)\end{array}$ \\
\hline \multicolumn{4}{|l|}{ Interactions } \\
\hline Depth x Scale & - & - & $\begin{array}{c}-0.08^{* * *} \\
(0.01)\end{array}$ \\
\hline Breadth x Scale & - & - & $\begin{array}{c}0.01 \\
(0.02)\end{array}$ \\
\hline Local networks x Scale & - & - & $\begin{array}{l}-0.03 * \\
(0.01)\end{array}$ \\
\hline Prestige x Scale & - & - & $\begin{array}{l}-0.02 \\
(0.03)\end{array}$ \\
\hline Depth x Scope & - & - & $\begin{array}{c}0.04 \\
(0.03)\end{array}$ \\
\hline Breadth x Scope & - & - & $\begin{array}{c}0.47^{* * *} \\
(0.08)\end{array}$ \\
\hline Local networks x Scope & - & - & $\begin{array}{l}-0.02 \\
(0.5)\end{array}$ \\
\hline Prestige x Scope & - & - & $\begin{array}{c}0.05 \\
(0.11)\end{array}$ \\
\hline Maximum VIF value & 1.13 & 1.70 & 2.22 \\
\hline Wald & $23.77^{* * *}$ & $28.98^{* * *}$ & $32.36^{* * *}$ \\
\hline
\end{tabular}


$\mathrm{N}=1982$ for 377 firms. Note: Standard errors are in parentheses. All models include a constant. $+\mathrm{P}<.10$

$* \mathrm{P}<0.05$

$* * \mathrm{P}<0.01$

$* * * \mathrm{P}<0.001$.

Hypothesis 1a predicted that boards' depth of international experience would be positively associated with firm performance.. Results from the GEE regression analysis provide support for this hypothesis $(\mathrm{B}=0.06$; $\mathrm{p}$-value $<0.001)$. Hypothesis $1 \mathrm{~b}$ predicted that boards' breadth of international experience would be positively associated with firm performance. This hypothesis was also supported by the results. Hypothesis 1c predicted that boards' international social capital is positively associated with firm performance. The regression coefficient for social networks in model 2 is nonsignificant, while the coefficient for board prestige is positive and significant $(B=0.41$; $p$-value $<0.001)$. Thus, the results from the GEE regression analysis provide partial support for this hypothesis.

Hypothesis 2a predicted that the relationship between boards' depth of international capital and firm performance would be negatively moderated by scale of internationalization such that depth has a stronger relationship with performance at earlier stages of internationalization. The significant, negative coefficient for this interaction $(B=-0.084 ; p$-value $<0.001)$ in model 3 indicates support for this hypothesis. Hypothesis $2 \mathrm{~b}$ predicted that the relationship between boards' international social capital and firm performance would also be moderated by scale of internationalization such that social capital has a stronger relationship with performance at earlier stages of internationalization. The coefficient for the interaction between prestige and scale is 
nonsignificant. However, the negative and significant coefficient of the interaction between local networks and scale provide partial support for this hypothesis $(B=-0.03$; $p$ value $<0.05$ ). Hypothesis $2 \mathrm{c}$ predicted that the relationship between boards' breadth of international capital and firm performance would be moderated by scale of internationalization such that breadth has a stronger relationship with performance at later stages of internationalization. The regression results do not provide support for hypothesis $2 \mathrm{c}$.

Finally, hypothesis 3 predicted that the relationship between boards' breadth of international capital and firm performance would be moderated by firms' scope of internationalization such that board capital breadth has a stronger relationship with performance at higher levels of scope. Regression results provide strong support for hypothesis $3(\mathrm{~B}=0.47$; p-value $<0.001)$.

\section{DISCUSSION AND CONCLUSION}

The purpose of this study was to examine the effect of international board capital on firm performance for MNEs as they engage in internationalization. More specifically, I explored how the effect of different forms of board capital on firm performance varied depending on the characteristics (i.e. scale and scope) of the firm's internationalization. Drawing from resource dependence theory and the internationalization and performance literature, I argued and found that international board capital depth and social capital have stronger effects on MNE performance when firms are at earlier stages of internationalization. These findings suggest that the deep knowledge of local markets, access to crucial resources, and legitimacy that board capital can provide are more 
important to firms in the earlier stages of internationalization, when they tend to lack these key resources.

I also found that breadth of international board capital has a stronger effect on firm performance at higher levels of scope. This provides empirical support for my argument that the additional information-processing capabilities obtained through a breadth of international experience allows directors to provide important advice and counsel to firms with more complex international operations. Contrary to my predictions, I did not find a significant interaction effect between board capital breadth and scale of internationalization on MNE performance. This result may suggest that increasing the scale of internationalization across only a few geographic markets may not increase the complexity of operations as substantially as increasing the scope of internationalization. Thus, boards' breadth of international experience is most relevant when firms have a broad geographic reach.

Overall, the findings of this study have important implications for scholarly research in the area of corporate governance. While corporate governance scholars have long acknowledged that boards with relevant knowledge and expertise should be more effective in providing useful advice and counsel to the firms (e.g. Carpenter \& Westphal, 2001; Haynes \& Hillman, 2010), very few studies have attempted to clarify the boundary conditions under which certain forms of board capital have stronger or weaker effects on firm-level performance outcomes (Kor \& Sundaramurthy, 2009; McDonald et al., 2008). By deconstructing the "board capital" construct into breadth, depth, and social capital components, and by integrating insights from internationalization literature, I sought in this study to clarify the conditions under which specific forms of board capital can fill the 
voids of firms lacking the necessary resources to successfully execute a particular strategy. The findings of this study demonstrate that since different stages of the internationalization process are accompanied by distinct challenges requiring distinct knowledge and experience, the nature and form of boards' human and social capital will become more or less important depending upon the specific strategic needs of the firm. This study highlights the importance of considering the interaction of board characteristics with contextual factors to predict boards' ultimate effect on firm outcomes.

In spite of the aforementioned contributions, this study has several limitations that present opportunities for future research. Perhaps the most obvious limitation is that I focus only on large, public, US-based firms. Similar to other board studies, my primary motivations in focusing on these firms were to ensure access to consistent, reliable data (e.g. Harrison \& Coombs, 2012; Lester et al, 2008), and to limit variance in the outcome variable caused by differences in country-level governance features (e.g. Dalziel et al., 2011). Although this context was appropriate for this study in many regards, it would be interesting for future researchers to investigate whether these findings hold in other country contexts and for smaller and/or private firms. Additionally, my use of secondary data does not allow me to directly examine the relationship between the possession of board capital and the provision of strategic resources as hypothesized in this study. While this is a common limitation shared across the majority of empirical studies on boards, (Johnson et al., 2013), it also presents a great opportunity for future researchers to further delve into the resource provision role of boards during the internationalization process 
and perhaps expose additional contingencies, moderators, and mediators in the aforementioned relationships.

In conclusion, I find that the effect of boards' human and social capital on MNE performance is highly contingent upon the strategic needs of the firm. The findings of this study facilitate a better understanding of the specific knowledge, expertise, and social ties the board can utilize for the benefit of firms and provides insight into how these dimensions of board capital shape board functions and effectiveness. The findings also suggest that the application of board capital literature to firms' international strategic choices and outcomes is a venue well worth future research, and deserves further attention from IB and strategy scholars. I believe that future studies that take a similar fine-grained, multitheoretical approach to exploring boards' ability to positively influence firm-level performance outcomes will be valuable and impactful. 


\section{REFERENCES}

\section{ESSAY 1 REFERENCES}

Arthaud-Day, M. L., Certo, S. T., Dalton, C. M., \& Dalton, D. R. 2006. A changing of the guard: Executive and director turnover following corporate financial restatements. Academy of Management Journal, 49: 1119-1136.

Becker G., 1975. Human Capital. Columbia University Press: New York.

Berle, A., \& Means, G. 1932. The modern corporation and private property. New York: Macmillan.

Certo, S. T. 2003. Influencing initial public offering investors with prestige: Signaling with board structures. Academy of Management Review, 28(3), 432-446.

Connelly, B. L., Johnson, J. L., Tihanyi, L., \& Ellstrand, A. E. 2011. More than adopters: Competing influences in the interlocking directorate. Organization Science, 22: 688703.

Cowen, A. P., \& Marcel, J. J. 2011. Damaged goods: Board decisions to dismiss reputationally compromised directors. Academy of Management Journal, 54: 509527.

Daily, C. M., Dalton, D. R., \& Cannella, A. A., Jr. 2003. Corporate governance: Decades of dialogue and data. Academy of Management Review, 28(3): 371-382.

Dalziel, T., Gentry, R. J., \& Bowerman, M. 2011. An integrated agency-resource dependence view of the influence of directors' human and relational capital on firms' R\&D spending. Journal of Management Studies, 48: 1217-1242.

Datta, D. K., Musteen, M., \& Herrmann, P. 2009. Board characteristics, managerial incentives, and the choice between foreign acquisitions and international joint ventures. Journal of Management, 35(4): 928-953.

Davis, G. F., \& Cobb, J. A. 2010. Resource dependence theory: Past and future. In C. B. Schoonhoven \& F. Dobbin (Eds.), Stanford's organization theory renaissance, 1970 2000 (Research in the sociology of organizations, Vol. 28): 21-42. London: Emerald.

Fama, E. 1980. Agency problems and the theory of the firm. Journal of Political Economy, 88: 288-307.

Geletkanycz, M.A., \& Hambrick, D.C. (1997). The external ties of top executives: Implications for strategic choice and performance. Administrative Science Quarterly, 42: 654-681. 
Golden, B. R., \& Zajac, E. J. 2001. When will boards influence strategy? Inclination $\times$ power = strategic change. Strategic Management Journal, 22: 1087-1111.

Haunschild, P. R. 1993. Interorganizational imitation: The impact of interlocks on corporate acquisition activity. Administrative Science Quarterly, 38: 564-592.

Haynes, K.T., \& Hillman, A. 2010. The effect of board capital and CEO power on strategic change. Strategic Management Journal, 31: 1145-1163.

Hillman, A.J. 2005. Politicians on the board: do connections affect the bottom line? Journal of Management, 31: 464-481.

Hillman, A.J., \& Dalziel, T. 2003. Boards of directors and firm performance: integrating agency and resource dependence perspectives. Academy of Management Review, 28(3): 383-396.

Hillman, A. J., Withers, M. C., \& Collins, B. J. 2009. Resource dependence theory: A review. Journal of Management, 35: 1404-1427.

Jensen, M.C., \& Meckling, W.H. 1976. Theory of the firm: Managerial behavior, agency costs, and ownership structure. Journal of Financial Economics, 3(4): 305-360.

Johnson, J. L., Ellstrand, A. E., \& Daily, C. M. 1996. Boards of directors: A review and research agenda. Journal of Management, 22: 409-438.

Johnson, S., Schnatterly, K., Bolton, J. F., \& Tuggle, C. 2011. Antecedents of new director social capital. Journal of Management Studies, 48: 1782-1803.

Kassinis, G., \& Vafeas, N. 2002. Corporate boards and outside stakeholders as determinants of environmental litiga- tion. Strategic Management Journal, 23: 399415.

Kroll, M., Walters, B. A., \& Le, S. A. 2007. The impact of board composition and top management team owner- ship structure on post-IPO performance in young entrepreneurial firms. Academy of Management Journal, 50: 1198-1216.

Kroll, M., Walters, B. A., \& Wright, P. 2008. Board vigilance, director experience, and corporate outcomes. Strategic Management Journal, 29: 363-382.

Kor, Y., \& Misangyi V. 2008. Outside directors' industry- specific experience and firms' liability of newness. Strategic Management Journal, 29: 1345-1355.

Kor, Y., Sundaramurthy, C. 2009. Experience-based human and social capital of outside directors. Journal of Management, 35(4): 981-1006. 
Lester, R.H., Hillman, A.J., Zardkoohi, A., \& Cannella, A.A. 2008. Former government officials as outside directors: The role of human and social capital. Academy of Management Journal, 51: 999-1013.

Lynall, M. D., Golden, B. R., \& Hillman, A. J. 2003. Board composition from adolescence to maturity: A multi- theoretic view. Academy of Management Review, 28: 416-431.

McDonald, M. L., Westphal, J. D., \& Graebner, M. E. 2008. What do they know? The effects of outside director acquisition experience on firm acquisition performance. Strategic Management Journal, 29: 1155-1177.

Mizruchi, M.S. 1992. The structure of corporate political action: Interfirm relations and their consequences. Cambridge: Harvard University Press.

Mizruchi, M. S., \& Stearns, L. B. 1994. A longitudinal-study of borrowing by large American corporations. Administrative Science Quarterly, 39: 118-140.

Mizruchi, M.S., Stearns, L.B., \& Marquis, C. 2006. The conditional nature of embeddedness: A study of borrowing by large U.S. firms, 1973-1994. American Sociological Review, 71: 310-333.

Palmer, D., Jennings, P.D., \& Zhou, X. 1993. "Late adoption of the multidivisional form by large U.S. corporations: Institutional, political, and economic accounts. Administrative Science Quarterly, 38:100-131.

Pfeffer, J. 1972. Size and composition of corporate boards of directors. Administrative Science Quarterly, 17: 218-229.

Pfeffer, J., \& Salancik, G.R. 1978. The External Control of Organizations: A Resource Dependence Perspective. Harper \& Row: New York.

Provan, K.G. 1980. Recognizing, measuring, and interpreting the potential/enacted power distinction in organizational research. Academy of Management Review, 5: 549-560.

Provan, K. G., Beyer, J. M., \& Kruytbosch, C. 1980. Environmental linkages and power in resource- dependence relations between organizations. Administrative Science Quarterly, 25: 200-225.

Sanders, W.M.G., \& Carpenter, M.A. 1998. Internationalization and firm governance: The roles of CEO compensation, top team composition, and board structure. Academy of Management Journal, 41: 158-178.

Stearns, L. B., \& Mizruchi, M. S. 1993. Board composition and corporate financing: The impact of financial institution representation on borrowing. Academy of Management Journal, 36: 603-618. 
Stuart, T. E., \& Yim, S. 2010. Board interlocks and the propensity to be targeted in private equity transactions. Journal of Financial Economics, 97: 174-189.

Sundaramurthy, C., Pukthuanthong, K., \& Kor, Y. 2013. Positive and negative synergies between the CEO's and the corporate board's human and social capital: A study of biotechnology firms. Strategic Management Journal forthcoming. doi: $10.1002 /$ smj. 2137

Thompson, J. D. (1967). Organizations in Action. McGraw Hill, New York.

Tihanyi, L., Johnson, R. A., Hoskisson, R. E., \& Hitt, M. A. 2003. Institutional ownership differences and international diversification: The effects of boards of directors and technological opportunity. Academy of Management Journal, 46(2): 195-211.

\section{ESSAY 2 REFERENCES}

Adams, R.B., \& Ferreira, D. 2007. A Theory of Friendly Boards. Journal of Finance, 62(1): 217-250.

Applebaum, S.H. \& Gandell, J. 2003. A cross method analysis of the impact of culture and communications upon a health care merger: Prescriptions for human resources management. The Journal of Management Development, 22(5/6): 370-409.

Barkema, H.G., Bell, J.H.J., \& Pennings, J.M., 1996. Foreign entry, cultural barriers and learning. Strategic Management Journal, 17: 151-166.

Barkema, H. G. \& Schijven, M. 2008. How do firms learn to make acquisitions? A review of past research and an agenda for the future. Journal of Management, 34: 594-634.

Capron, L., \& Guillen, M. 2009. National corporate governance institutions and postacquisition target reorganization. Strategic Management Journal, 30: 803-833.

Carpenter, M., Sanders, G., Gregersen, H., 2001. Bundling human capital with organizational context: The impact of international assignment experience on multinational firm performance and CEO pay. Academy of Management Journal 44(3): 493-511.

Chakrabarti, R., Jayaraman, N., \& Gupta-Mukherjee, S. 2009. Mars-Venus marriages: Culture and cross-border M\&A. Journal of International Business Studies, 40(2): 216-236.

Cohen, L., Frazzini, A., \& Malloy, C. 2008. Hiring Cheerleaders: Board Appointments of "Independent" Directors. Harvard Business School Working Paper. 
Contractor, F.J., Kundu, S.K., \& Hsu, C. 2003. A three-stage theory of international expansion: The link between multinationality and performance in the service sector. Journal of International Business Studies, 34:5-18.

Daily, C. M., Dalton, D. R., \& Cannella, A. A., Jr. 2003. Corporate governance: Decades of dialogue and data. Academy of Management Review, 28(3): 371-382.

Datta, D.K., Musteen, M., \& Herrmann, P. 2009. Board characteristics, managerial incentives, and the choice between foreign acquisitions and international joint ventures. Journal of Management, 35(4): 928-953.

Datta, D.K., \& Puia, G. 1995. Cross-border acquisitions: An examination of the influence of relatedness and cultural fit on shareholder value creation in U.S. acquiring firms. Management International Review, 35(4): 337-359.

de Villiers, C., Naiker, V., \& van Staden, C.J. 2011. The effect of board characteristics on firm environmental performance. Journal of Management, 37: 1636-1663.

Denis, D. J., Denis, D. K., \& Yost, K. 2002. Global diversification, industrial diversification, and firm value. Journal of Finance, 57: 1951-1979.

Doukas, J., \& Travlos, N. G. 1988. The effect of corporate multinationalism on shareholders' wealth: Evidence from international acquisitions. Journal of Finance, 43(5): 1161-1175.

Dutton, G. 1999. Building a global brain. Management Review, 88(5): 23-30.

Ellis, K. M., Reus, T. H., \& Lamont, B. T. 2009. The effects of procedural justice and informational justice in the integration of related acquisitions. Strategic Management Journal, 30(2): 137-161.

Finkelstein, S., Hambrick, D.C., \& Cannella, A. A., Jr. 2009. Strategic Leadership: Theory and Research on Executives, Top Management Teams, and Boards. Oxford University Press, USA.

Forbes, D.P., \& Milliken, F.J. 1999. Cognition and corporate governance: Understanding boards of directors as strategic decision-making groups. Academy of Management Review, 24: 489-505.

Gleason, K.C., Mathur, I., \& Wiggins III, R.A. 2006. The use of acquisitions and joint ventures by U.S. banks expanding abroad. Journal of Financial Research, 29(4): 503522.

Gomes, L., \& Ramaswamy, K. 1999. An empirical examination of the form of the relationship between multinationality and performance. Journal of International Business Studies, 30(1): 173-188. 
Gomez-Mejia, L.R. \& Palich, L. (1997). Cultural diversity and the performance of multinational firms. Journal of International Business Studies, 28(2): 309-335.

Gregersen, H.B., Morrison, A.J. \& Black, J.S. 1998. Developing leaders for the global frontier. Sloan Management Review, Fall: 21-32.

Gupta, A.K. \& Govindarajan, V. 2002. Cultivating a global mindset. Academy of Management Executive, 16(1): 116-126.

Haleblian, J., \& Finkelstein, S. 1999. The influence of organizational acquisition experience on acquisition performance: A behavioral learning perspective. Administrative Science Quarterly, 44: 29-56.

Han, K.C., Lee, S.H., \& Suk, D.Y. 1998. Multinationality and firm performance. Multinational Business Review. 6(2): 63-70.

Hansen, M.T., \& Lovas, B. 2004. How do multinational companies leverage technological competencies? Moving from single to interdependent explanations. Strategic Management Journal, 25: 801-822.

Haveman, H., \& Cohen, L. 1994. The ecological dynamics of careers: the impact of organizational founding, dissolution and merger on job mobility. American Journal of Sociology, 100(1): 104-152.

Haynes, K.T., \& Hillman, A. 2010. The effect of board capital and CEO power on strategic change. Strategic Management Journal, 31: 1145-1163.

Hayward, M.L., \& Hambrick, D.C. 1997. Explaining the premiums paid for large acquisitions: Evidence of CEO hubris. Administrative Science Quarterly, 42: 103127.

Hennart, J.F. 2007. The theoretical rationale for a multinationality-performance relationship. Management International Review, 47(3): 423-452.

Hillman, A.J. 2005. Politicians on the board: do connections affect the bottom line? Journal of Management, 31: 464-481.

Hillman, A.J., \& Dalziel, T. 2003. Boards of directors and firm performance: integrating agency and resource dependence perspectives. Academy of Management Review, 28(3): 383-396.

Hillman, A.J., Shropshire, C., \& Cannella, A. 2007. Organizational predictors of women on corporate boards. Academy of Management Journal, 50: 941-952.

Hillman, A.J., Withers, M. C., \& Collins, B. J. 2009. Resource dependence theory: A review. Journal of Management, 35(6): 1404-1427. 
Hitt, M.A., Harrison, J.S., \& Ireland, R.D., 2001. Mergers and Acquisitions: A Guide to Creating Value for Stakeholders. Oxford Univ. Press, New York.

Hitt, M. A., King, D., Krishnan, H., Makri, M., Schijven, M., Shimizu, K., \& Zhu, H. 2009. Mergers and acquisitions: Overcoming pitfalls, building synergy and creating value. Business Horizons, 52: 523-529.

Huse, M. \& Gabrielsson, J. 2012. Board leadership and value creation: An extended team production approach, in Clarke, T. \& Branson, D. (eds.), The SAGE Handbook of Corporate Governance, London: Sage Publications.

Hymer, S. H. 1960. The international operations of national firms: A study of direct foreign investment. Doctoral dissertation, Massachusetts Institute of Technology, Cambridge, MA.

Jemison, D. B. 1988. Value creation and acquisition integration: The role of strategic capability transfer. G. Liebcap, ed. Advances in the Study of Entrepreneurship, Innovation, and Economic Growth. JAI Press, Greenwich, CT, 191-218.

Johnson, S., Schnatterly, K.A. \& Hill, A. 2013. Board Composition Beyond Independence: Social Capital, Human Capital, and Demographics. Journal of Management, 39(1): 232-262.

Kassinis, G., \& Vafeas, N. 2002. Corporate boards and outside stakeholders as determinants of environmental litigation. Strategic Management Journal, 23: 399415.

King, D.R., Dalton, D.R., Daily, C.M., \& Covin, J.G. 2004. Meta-analyses of postacquisition performance: indications of unidentified moderators. Strategic Management Journal, 25: 187-200.

Kissin, W.D., \& Herrera, J., 1990. International mergers and acquisitions. Journal of Business Strategy, 11: 51-55.

Kogut, B. \& Singh, H. 1988. The effect of national culture on the choice of entry mode. Journal of International Business Studies, 19(3): 411-432.

Kroll, M., Walters, B.A., \& Le, S.A. 2007. The impact of board composition and top management team owner- ship structure on post-IPO performance in young entrepreneurial firms. Academy of Management Journal, 50: 1198-1216.

Kroll, M., Walters, B. A., \& Wright, P. 2008. Board vigilance, director experience, and corporate outcomes. Strategic Management Journal, 29: 363-382.

Larsson, R., \& Finkelstein, S. 1999. Integrating strategic, organizational, and human resource perspectives on mergers and acquisitions: A case survey of synergy realization. Organization Science, 10(1): 1-26. 
Lau, D., \& Murnighan, J.K. 1998. Demographic diversity and faultlines: The compositional dynamics of organizational groups. Academy of Management Review, 23: $325-340$.

Lester, R.H., Hillman, A.J., Zardkoohi, A., \& Cannella, A.A. 2008. Former government officials as outside directors: The role of human and social capital. Academy of Management Journal, 51: 999-1013.

Lovvorn, A. S., \& Chen, J. S. 2011. Developing a global mindset: The relationship between and international assignment and cultural intelligence. International Journal of Business and Social Science, 2(9): 271-283.

Lu, J.W. \& Beamish, P.W. 2004. International diversification and firm performance: the s-curve hypothesis. Academy of Management Journal, 47(4): 598-609.

Lynall, M.D., Golden, B.R., \& Hillman, A.J. 2003. Board composition from adolescence to maturity: A multi-theoretic view. Academy of Management Review, 28: 416-431.

Markides, C.C., \& Oyon, D. 1998. International acquisitions: Do they create value for shareholders? European Management Journal, 16(2): 125-135.

McDonald, M.L., Westphal, J.D., \& Graebner, M.E. 2008. What do they know? The effects of outside director acquisition experience on firm acquisition performance. Strategic Management Journal, 29: 1155-1177.

Mesmer-Magnus, J. R., \& DeChurch, L. A. 2009. Information sharing and team performance: A meta-analysis. Journal of Applied Psychology, 94: 535-546.

Moeller, S.B., \& Schlingemann, F.P. 2005. Global diversification and bidder gains: A comparison between cross-border and domestic acquisitions. Journal of Banking and Finance, 29(3): 533-564.

Morck, R., \& Yeung, B. 1992. Internalization: An event study test. Journal of International Economics, 33(1-2): 41-56.

Morrison, A., Gregersen, H. \& Black, S. 1999. What makes savvy global leaders? IVEY Business Journal, November-December: 44-51.

Murtha, T., Lenway, S., \& Bagozzi, S. 1998. Global mindsets and cognitive shifts in a complex multinational corporation. Strategic Management Journal, 19: 97-114.

Nielsen, S. 2012. Diversity on boards. In Clarke, T. \& Branson, D. (eds.), The SAGE Handbook of Corporate Governance, London: Sage Publications, 345-362.

Oxelheim, L., \& Randoy, T. 2003. The impact of foreign board membership on firm value. Journal of Banking \& Finance, 27: 2369-2392. 
Pfeffer, J. \& Salancik, G. R. 1978. The External Control of Organizations: A Resource Dependence Perspective. New York: Harper and Row.

Sambharya, R. B. 1996. Foreign experience of top management teams and international diversification strategies of U.S. multinational corporations. Strategic Management Journal, 17: 739-746.

Sanders, W.M.G., \& Carpenter, M.A. 1998. Internationalization and firm governance: The roles of CEO compensation, top team composition, and board structure. Academy of Management Journal, 41: 158-178.

Schmidt, B. 2008. Costs and benefits of "friendly" boards during mergers and acquisitions. Working Paper, University of Southern California.

Scott, J. 1991. Social network analysis: A handbook. London: Sage.

Shimizu, K., Hitt, M.A., Vaidyanath, D., \& Pisano, V. 2004. Theoretical foundations of cross-border mergers and acquisitions: A review of current research and recommendations for the future. Journal of International Management, 10(3): 307353.

Short, J. 2009. The art of writing a review article. Journal of Management, 35: 13121317.

Stahl, G.K., \& Voigt, A. 2008. Do cultural differences matter in mergers and acquisitions? A tentative model and examination. Organization Science, 19: 160-176.

Staples, C.L. 2008. Cross-border acquisitions and board globalization in the world's largest TNCs, 1995-2005. Sociological Quarterly, 49: 31-49.

Steiner, I.D. 1972. Group process and productivity. New York: Academic Press.

Tallman, S., \& Li, J. 1996. Effects of international diversity and product diversity on the performance of multinational firms. Academy of Management Journal, 39(1): 179196.

Thomson Reuters. 2012. Mergers \& Acquisitions Review: Financial Advisors (Full Year 2012). New York, NY: Author. Retrieved from http://dmi.thomsonreuters.com/Content/Files/4Q2012_MA_Financial_Advisory_Revi ew.pdf

Tihanyi, L., Ellstrand, A. E., Daily, C. M., \& Dalton, D. R. 2000. Composition of the top management team and firm international diversification. Journal of Management, 26: 1157-1167. 
Tuggle, C.S., Schnatterly, K., Johnson, R.A. 2010. Attention patterns in the boardroom: how board composition and processes affect discussion of entrepreneurial issues. Academy of Management Journal, 53(3): 550-571.

Wasserman, S., \& Faust, K. 1994. Social network analysis: Methods and applications. Cambridge, U.K.: Cambridge University Press.

Westphal, J. D., \& Fredrickson, J. W. 2001. Who directs strategic change? Director experience, the selection of new CEOs, and change in corporate strategy. Strategic Management Journal, 22: 1113-1137.

Westphal, J.D. 1999. Collaboration in the boardroom: behavioral and performance consequences of CEO board social ties. Academy of Management Journal 42(1): 7 24.

Westphal, J.D., \& Bednar, M.K. 2005. Pluralistic ignorance in corporate boards and firms' strategic persistence in response to low firm performance. Administrative Science Quarterly 50(2): 262-298.

Zaheer, S., 1995. Overcoming the liability of foreignness. Academy of Management Journal. 38, 341-363.

Zhu, D.H. (2013). Group polarization on corporate boards: Theory and evidence on board decisions about acquisition premiums. Strategic Management Journal, 34(7): 800822.

Zollo M, \& Singh S. 2004. Deliberate learning in corporate acquisitions: post-acquisition strategies and integration capability in U.S. bank mergers. Strategic Management Journal, 25(12): 1233-1257.

Zollo, M., \& Meier, D. 2008. What is M\&A performance? Academy of Management Perspectives

\section{ESSAY 3 REFERENCES}

Arthaud-Day, M. L., Certo, S. T., Dalton, C. M., \& Dalton, D. R. 2006. A changing of the guard: Executive and director turnover following corporate financial restatements. Academy of Management Journal, 49: 1119-1136.

Becker G., 1975. Human Capital. Columbia University Press: New York.

Bouquet, C., Morrison, A., \& Birkinshaw, J. 2009. International attention and multinational enterprise performance. Journal of International Business Studies, 40(1): 108-131.

Brewer, H.L. 1981. Investor benefits from corporate international diversification. Journal of Financial and Quantitative Analysis, 16: 113-126. 
Buckley, P.J., \& Casson, M. 1976. The future of the multinational enterprise. New York: Holmes \& Meier.

Carpenter, M. A., Geletkanycz, M. A., \& Sanders, W. G. 2004. Upper echelons research revisited: Antecedents, elements, and consequences of top management team composition. Journal of Management, 30: 749-778.

Certo, S. T. 2003. Influencing initial public offering investors with prestige: Signaling with board structures. Academy of Management Review, 28(3), 432-446.

Coase, R. H. 1937. The Nature of the Firm. Economica, 4(16): 386-405.

Collins, J.M. 1990. A market performance comparison of US firms active in domestic, developed and developing countries. Journal of International Business Studies, 2: 271-287.

Connelly, B. L., Johnson, J. L., Tihanyi, L., \& Ellstrand, A. E. 2011. More than adopters: Competing influences in the interlocking directorate. Organization Science, 22: 688703.

Contractor, F. 2007. Is international business good for companies? The evolutionary or multi-stage theory of internationalization vs. the transaction cost perspective. Management International Review, 47(3): 453-475.

Contractor, F.J., Kundu, S.K., \& Hsu, C. 2003. A three stage theory of international expansion: The link between multinationality and performance in the service sector. Journal of International Business Studies, 34:5-18.

Cowen, A. P., \& Marcel, J. J. 2011. Damaged goods: Board decisions to dismiss reputationally compromised directors. Academy of Management Journal, 54: 509527.

Daily, C. M., Dalton, D. R., \& Cannella, A. A., Jr. 2003. Corporate governance: Decades of dialogue and data. Academy of Management Review, 28(3): 371-382.

Dalziel, T., Gentry, R. J., \& Bowerman, M. 2011. An integrated agency-resource dependence view of the influence of directors' human and relational capital on firms' R\&D spending. Journal of Management Studies, 48: 1217-1242.

Daniels, J.D. \& Bracker, J. 1989. Profit performance: Do foreign operations make a difference? Management International Review, 29: 46-56.

Datta, D. K., Musteen, M., \& Herrmann, P. 2009. Board characteristics, managerial incentives, and the choice between foreign acquisitions and international joint ventures. Journal of Management, 35(4): 928-953. 
Davis, G. F., \& Cobb, J. A. 2010. Resource dependence theory: Past and future. In C. B. Schoonhoven \& F. Dobbin (Eds.), Stanford's organization theory renaissance, 1970 2000 (Research in the sociology of organizations, Vol. 28): 21-42. London: Emerald.

Delios, A., \& Beamish, P. W. 1999. Geographic scope, product diversification and the corporate performance of Japanese firms. Strategic Management Journal, 20: 711721.

Denis, D. J., Denis, D. K., \& Yost, K. 2002. Global diversification, industrial diversification, and firm value. Journal of Finance, 57: 1951-1961.

Fama, E. F., \& Jensen, M. C. 1983. Agency problems and residual claims. Journal of Law and Economics, 26(2): 327-349.

Geletkanycz, M.A., \& Hambrick, D.C. (1997). The external ties of top executives: Implications for strategic choice and performance. Administrative Science Quarterly, 42: 654-681.

Goerzen, A., \& Beamish, P.W. 2003. Geographic scope and multinational enterprise performance. Strategic Management Journal, 24: 1289-1306.

Golden, B. R., \& Zajac, E. J. 2001. When will boards influence strategy? Inclination $\times$ power $=$ strategic change. Strategic Management Journal, 22: 1087-1111.

Gomes, L., \& Ramaswamy, K. 1999. An empirical examination of the form of the relationship between multinationality and performance. Journal of International Business Studies, 30: 173-183.

Gomez-Mejia, L. R., \& Palich, L. E. 1997. Cultural diversity and the performance of multinational firms. Journal of International Business Studies, 28: 309-335.

Grant, R.M. 1987. Multinationality and performance among British manufacturing companies. Journal of International Business Studies, 18: 79-90.

Gregersen, H.B., Morrison, A.J. \& Black, J.S. 1998. Developing leaders for the global frontier. Sloan Management Review, Fall: 21-32.

Gupta, A.K. \& Govindarajan, V. 2002. Cultivating a global mindset. Academy of Management Executive, 16(1): 116-126.

Han, K. C., Lee, S. H., \& Suk, D. Y. 1998. Multinationality and firm performance. Multinational Business Review, 6(2): 63-70.

Haunschild, P. R. 1993. Interorganizational imitation: The impact of interlocks on corporate acquisition activity. Administrative Science Quarterly, 38: 564-592. 
Haynes, K.T., \& Hillman, A. 2010. The effect of board capital and CEO power on strategic change. Strategic Management Journal, 31: 1145-1163.

Hennart, J.F. 2007. The theoretical rationale for a multinationality-performance relationship. Management International Review, 47(3): 423-452.

Hillman, A.J. 2005. Politicians on the board: do connections affect the bottom line? Journal of Management, 31: 464-481.

Hillman, A.J., \& Dalziel, T. 2003. Boards of directors and firm performance: integrating agency and resource dependence perspectives. Academy of Management Review, 28(3): 383-396.

Hillman, A. J., Withers, M. C., \& Collins, B. J. 2009. Resource dependence theory: A review. Journal of Management, 35: 1404-1427.

Hitt, M.A., Hoskisson, R.E., \& Kim, H. 1997. International diversification: Effects on innovation and firm performance in product-diversified firms. Academy of Management Journal, 40(4): 767-798.

Hitt, M. A., Ireland, R. D., \& Hoskisson, R. E. 2007. Strategic management: Competitiveness and globalization ( $7^{\text {th }}$ ed.). Mason, $\mathrm{OH}$ : South-Western.

Hitt, M. A., Tihanyi, L., Miller, T., \& Connelly, B. 2006. International diversification: Antecedents, outcomes, and moderators. Journal of Management, 32: 831-867.

Hsu, C.C., \& Boggs, D.J. (2003). Internationalization and performance: Traditional measures and their decomposition. Multinational Business Review, 11: 23-49.

Hymer, S.H. 1960 (1976). The international operations of national firms: A study of direct foreign investment. Doctoral dissertation, Massachusetts Institute of Technology, Cambridge, MA.

Jensen, M.C., \& Meckling, W.H. 1976. Theory of the firm: Managerial behavior, agency costs, and ownership structure. Journal of Financial Economics, 3(4): 305-360.

Johanson, J. \& Vahlne, J.E. (1977). The internationalization process of the firm: a model of knowledge development and increasing foreign market commitments. Journal of International Business Studies, 8(1): 23-32.

Johnson, J. L., Ellstrand, A. E., \& Daily, C. M. 1996. Boards of directors: A review and research agenda. Journal of Management, 22: 409-438.

Johnson, S., Schnatterly, K., Bolton, J. F., \& Tuggle, C. 2011. Antecedents of new director social capital. Journal of Management Studies, 48: 1782-1803. 
Kassinis, G., \& Vafeas, N. 2002. Corporate boards and outside stakeholders as determinants of environmental litigation. Strategic Management Journal, 23: 399415.

Kim, W.C., Hwang, P., \& Burgers, W.P. 1993. Multinationals' diversification and the risk-return trade-off. Strategic Management Journal, 14(4):275-286.

Kirca, A.H., Hult, G.T.M., Deligonul S.Z., Perry, M.Z., \& Cavusgil, S.T. 2012. Multilevel examination of the drivers of firm multinationality: a meta-analysis. Journal of Management, 32(8): 502-530.

Kogut, B. 1985. Designing global strategies: profiting from operational flexibility. Sloan Management Review, 26: 27-38.

Kotabe, M., Srinivasan, S. S., \& Aulakh, P. S. 2002. Multinationality and firm performance: The moderating role of R\&D and marketing capabilities. Journal of International Business Studies, 33: 79-89.

Kroll, M., Walters, B. A., \& Le, S. A. 2007. The impact of board composition and top management team owner- ship structure on post-IPO performance in young entrepreneurial firms. Academy of Management Journal, 50: 1198-1216.

Kroll, M., Walters, B. A., \& Wright, P. 2008. Board vigilance, director experience, and corporate outcomes. Strategic Management Journal, 29: 363-382.

Kor, Y., \& Misangyi V. 2008. Outside directors' industry- specific experience and firms' liability of newness. Strategic Management Journal, 29: 1345-1355.

Kor, Y., Sundaramurthy, C. 2009. Experience-based human and social capital of outside directors. Journal of Management, 35(4): 981-1006.

Lester, R.H., Hillman, A.J., Zardkoohi, A., \& Cannella, A.A. 2008. Former government officials as outside directors: The role of human and social capital. Academy of Management Journal, 51: 999-1013.

Lovvorn, A. S., \& Chen, J. S. 2011. Developing a global mindset: The relationship between and international assignment and cultural intelligence. International Journal of Business and Social Science, 2(9): 271-283.

Lu, J. W., \& Beamish, P. W. 2001. The internationalization and performance of SMEs. Strategic Management Journal, 22: 565-575.

Lu, J. W., \& Beamish, P. W. 2004. International diversification and firm performance: The S-curve hypothesis. Academy of Management Journal, 47: 598-608. 
Lynall, M. D., Golden, B. R., \& Hillman, A. J. 2003. Board composition from adolescence to maturity: A multi- theoretic view. Academy of Management Review, 28: 416-431.

McDonald, M. L., Westphal, J. D., \& Graebner, M. E. 2008. What do they know? The effects of outside director acquisition experience on firm acquisition performance. Strategic Management Journal, 29: 1155-1177.

Mizruchi, M.S. 1992. The structure of corporate political action: Interfirm relations and their consequences. Cambridge: Harvard University Press.

Mizruchi, M. S., \& Stearns, L. B. 1994. A longitudinal-study of borrowing by large American corporations. Administrative Science Quarterly, 39: 118-140.

Mizruchi, M.S., Stearns, L.B., \& Marquis, C. 2006. The conditional nature of embeddedness: A study of borrowing by large U.S. firms, 1973-1994. American Sociological Review, 71: 310-333.

Morck, R. and Yeung, B. 1991. Why investors value multinationality. Journal of Business, 64(20): 165-187.

Morrison, A., Gregersen, H. \& Black, S. 1999. What makes savvy global leaders? IVEY Business Journal, November-December: 44-51.

Murtha, T., Lenway, S., \& Bagozzi, S. 1998. Global mindsets and cognitive shifts in a complex multinational corporation. Strategic Management Journal, 19: 97-114.

Nachum, L., \& Zaheer, A. 2005. The persistence of distance? The impact of technology on MNE motivations for foreign investment. Strategic Management Journal, 26: 747767.

Nahapiet, J. \& Ghoshal, S. (1998). Social capital, intellectual capital, and the organizational advantage. Academy of Management Review, 23, 242-66.

Oxelheim, L., \& Randoy, T. 2003. The impact of foreign board membership on firm value. Journal of Banking \& Finance, 27: 2369-2392.

Palmer, D., Jennings, P.D., \& Zhou, X. 1993. "Late adoption of the multidivisional form by large U.S. corporations: Institutional, political, and economic accounts.

Administrative Science Quarterly, 38:100-131.

Pfeffer, J. 1972. Size and composition of corporate boards of directors. Administrative Science Quarterly, 17: 218-229.

Pfeffer, J., \& Salancik, G.R. 1978. The External Control of Organizations: A Resource Dependence Perspective. Harper \& Row: New York. 
Porter, M. E. 1990. The competitive advantage of nations. New York: Free Press.

Provan, K.G. 1980. Recognizing, measuring, and interpreting the potential/enacted power distinction in organizational research. Academy of Management Review, 5: 549-560.

Provan, K. G., Beyer, J. M., \& Kruytbosch, C. 1980. Environmental linkages and power in resource- dependence relations between organizations. Administrative Science Quarterly, 25: 200-225.

Ramaswamy, K. 1995. Multinationality, configuration, and performance: A study of MNEs in the U.S. drug and pharmaceutical industry. Journal of International Management, 1(2): 231-253.

Rugman, A.M. 1976. Risk reduction by international diversification. Journal of International Business Studies, 7: 75-80.

Rugman, A.M. 1981. Inside the multinationals: The economics of international markets. London: Croom Helm.

Rugman, A.M., \& Sukpanich, N., 2006. Firm-specific advantages intra-regional sales and performance of multinational enterprises. The International Trade Journal, 20(3): $355-382$.

Ruigrok, W., \& Wagner, H. 2003. Internationalization and performance: An organizational learning perspective. Management International Review, 43: 63-73.

Sanders, W.M.G., \& Carpenter, M.A. 1998. Internationalization and firm governance: The roles of CEO compensation, top team composition, and board structure. Academy of Management Journal, 41: 158-178.

Staples, C.L. 2008. Cross-border acquisitions and board globalization in the world's largest TNCs, 1995-2005. Sociological Quarterly, 49: 31-49.

Stearns, L. B., \& Mizruchi, M. S. 1993. Board composition and corporate financing: The impact of financial institution representation on borrowing. Academy of Management Journal, 36: 603-618.

Stuart, T. E., \& Yim, S. 2010. Board interlocks and the propensity to be targeted in private equity transactions. Journal of Financial Economics, 97: 174-189.

Subramaniam, M. \& Youndt, M.A. (2005). The influence of intellectual capital on the types of innovative capabilities. Academy of Management Journal, 48: 450-463.

Suchman, M.C. 1995. Managing legitimacy: Strategic and institutional approaches. Academy of Management Review, 20: 571-610. 
Sullivan, D. 1994. Measuring the degree of internationalization of a firm. Journal of International Business Studies, 25: 325-342.

Sundaramurthy, C., Pukthuanthong, K., \& Kor, Y. 2013. Positive and negative synergies between the CEO's and the corporate board's human and social capital: A study of biotechnology firms. Strategic Management Journal forthcoming. doi: $10.1002 / \mathrm{smj} .2137$

Tallman, S., \& Li, J. 1996. Effects of international diversity and product diversity on the performance of multina- tional firms. Academy of Management Journal, 39: 179-189.

Thomas, D.E. \& Eden, L. 2004. What is the shape of the multinationality-performance relationship? Multinational Business Review, 12(1): 89-101.

Tihanyi, L., Johnson, R. A., Hoskisson, R. E., \& Hitt, M. A. 2003. Institutional ownership differences and international diversification: The effects of boards of directors and technological opportunity. Academy of Management Journal, 46(2): 195-211.

Tihanyi, L., \& Thomas, W. B. 2005. Information-processing demands and the multinational enterprise: A comparison of foreign and domestic earnings estimates. Journal of Business Research, 58: 285-292.

Vermeulen, F., \& Barkema, H. 2002. Pace, rhythm, and scope: Process dependence in building a profitable multi- national corporation. Strategic Management Journal, 23: 637-647.

Wernerfelt, B. (1984). A resource-based view of the firm. Strategic Management Journal, 5(2): 171-180.

Zaheer, S. 1995. Overcoming the liability of foreignness. Academy of Management Journal, 38: 341-363. 
VITA

\section{WHITNEY G. DOUGLAS FERNANDEZ}

Bachelor of Business Administration, Finance

Texas A\&M University

College Station, Texas

Master of Science, Human Resource Development

Texas A\&M University

College Station, Texas

\section{PUBLICATIONS AND PRESENTATIONS}

International board capital and MNE performance: The moderating effects of internationalization scale and scope, Strategic Management Society Conference, September 2014 (forthcoming), Madrid, Spain.

Women in the boardroom and community stakeholder performance: A cognitive perspective (with M.F. Burnett), Academy of Management Conference, August 2014 (forthcoming), Philadelphia, USA.

Board capital and cross-border M\&A performance-The moderating role of internal social ties, Academy of International Business Conference, June 2014, Vancouver, Canada.

Boards of directors and the adoption of novel practices: Integrating network and heterogeneity perspectives (with J.M. Geleilate), Strategic Management Society Conference, October 2013, Atlanta, USA.

Environmental munificence, prior experience, and the prevalence of cross-border M\&As (with R. Zakaria and W.D. Schneper), Academy of Management Conference, August 2013, Orlando, USA.

The effect of board capital on internationalization strategy (with S.K. Kundu), Academy of International Business Conference, July 2013, Istanbul, Turkey.

Beyond institutional voids: Institutional dynamics and firm strategies (with C. Dhanaraj and S.K. Kundu), Academy of International Business Conference, July 2013, Istanbul, Turkey.

Legal Origins, Democracy, and Environmental Technology Innovation (with J. Rivera), Academy of International Business Conference, July 2013, Istanbul, Turkey. 
Board heterogeneity, board connectedness, and the adoption of innovations, Strategic Management Society Conference, October 2012, Prague, Czech Republic.

Board diversity, voluntary initiatives, and CSR towards employee stakeholders (with M.F. Burnett), Academy of Management Conference, August 2012, Boston, USA.

Environmental munificence, prior experience, and the prevalence of cross-border M\&As (with R. Zakaria and W.D. Schneper), Academy of International Business Conference, June 2012, Washington, D.C., USA.

MNCs and BOP markets: When can firms learn to find the fortune at the base of the pyramid? oikos Young Scholar Development Program, August 2011, Bangalore, India

Bottom of the pyramid markets: Entering the $4^{\text {th }}$ stage of international expansion, Academy of International Business Conference, June 2011, Nagoya, Japan 